\title{
Fundamental drivers of dependence in REIT returns
}

\author{
Jamie Alcock ${ }^{A}$ and Eva Steiner ${ }^{B *}$ \\ ${ }^{A}$ University of Sydney Business School \\ ${ }^{B}$ Department of Land Economy, University of Cambridge
}

\begin{abstract}
We analyse the empirical relationships between firm fundamentals and the dependence structure between individual REIT and stock market returns. In contrast to previous studies, we distinguish between the average systematic risk of REITs and their asymmetric risk in the sense of a disproportionate likelihood of joint negative return clusters between REITs and the stock market. We find that REITs with low systematic risk are typically small, with low short-term momentum, low turnover, high growth opportunities and strong long-term momentum. Holding systematic risk constant, the main driving forces of asymmetric risk are leverage and, to some extent, short-term momentum. Specifically, we find that leverage has an asymmetric effect on REIT return dependence that outweighs the extent to which it increases the average sensitivity of REIT equity to market fluctuations, explaining the strong negative impact of leverage on firm performance especially during crisis periods that has been documented in recent empirical work.
\end{abstract}

Key words: Portfolio Diversification, REITs, Real estate as an asset class, JEL Codes G11, G12

* Corresponding Author: Department of Land Economy, University of Cambridge, 19 Silver Street, Cambridge CB3 9EP, United Kingdom, Telephone: +44 (0) 1223337 152, Fax: +44 (0) 1223337 130, Email: es434@cam.ac.uk

We gratefully acknowledge financial support from RERI. Eva Steiner further acknowledges support from the Cambridge Endowment for Research in Finance.

We thank Man Cho, SE Ong, Shaun Bond, an anonymous referee, and seminar participants at the RERI Conference 2015 as well as the NUS-Maastricht-MIT Symposium 2015 for their helpful comments. 


\section{Introduction}

Periods of financial market turmoil typically lead to disproportionate joint declines in stock returns. ${ }^{1}$ Disproportionate joint negative return clusters between REITs and stocks are inconsistent with the common characterisation of REITs as defensive securities (Chan, Hendershott, and Sanders, 1990; Glascock and Hughes, 1995; Howe and Shilling, 1990). The returns of defensive stocks respond less than proportionally to market fluctuations, implying a CAPM beta of less than one on average. However, asymmetric dependence in the sense of disproportionate negative return clusters is independent of linear dependence measured by the CAPM beta, as illustrated in Figure 1. In other words, the CAPM beta contains little information on how a given security reacts to a significant market downturn.

\section{[Insert Figure 1 about here.]}

As a result, selecting stocks into a portfolio based on a low level of beta alone is insufficient to construct robust portfolios that are able to weather a downturn. ${ }^{2}$ Rather, effective stock selection requires the accurate identification of securities with low systematic risk (beta) and, simultaneously, a low likelihood of joint negative return clusters with stocks. In this study, we explore the fundamental firm-level drivers of systematic risk (beta) as well as asymmetric dependence independently of each other. Our results provide novel insights into the relationships between the returns on the stock market and the returns on REITs with different firm-level and financial characteristics, facilitating the identification of resilient firms in the construction of portfolios that are more robust to market downturns.

We are not the first to go beyond beta estimates in studying the joint evolution of investment returns from real estate (securities), REITs and other asset classes. Prior research has established three stylised facts about the dependence patterns of real estate security returns with respect to the broader market: (i) Benefits of diversification vary through time, (ii) they decrease in periods of higher uncertainty, and (iii) they also tend to dissipate during bear markets. However, the literature has produced limited insight into the fundamental economic drivers of dependence patterns in security returns. We contribute to the literature by identifying those firm characteristics that are empirically associated with the strongest ex ante impact on linear dependence and the likelihood of negative return clusters with the broader stock market.

\footnotetext{
1 Evidence for this stylised fact is found in various episodes of market turmoil, see, e.g., Ang and Bekaert (2002); Ang and Chen (2002); Ang, Chen, and Xing (2006); Hong, Tu, and Zhou (2007); Longin and Solnik (2001); Patton (2004). Similar return behaviour may be observed in real estate securities, as discussed, e.g., in Gordon (2009).

2 Clustering of poor returns occurs frequently in downturns and can significantly affect portfolio performance and asset prices (Ang and Bekaert, 2002; Ang, Chen, and Xing, 2006; Longin and Solnik, 2001; Patton, 2009).
} 
We study the firm-level fundamental determinants of linear dependence as measured by beta, separately and independently of the drivers of asymmetric dependence, using a simple test statistic based on exceedance correlations (Alcock and Hatherley, 2016; Hong, Tu, and Zhou, 2007). Our method stands in contrast to previous explorations on asymmetric dependence such as GARCH modelling or Copula functions. GARCH models describe time- and/or state-varying correlations and are therefore, much like the CAPM beta, unable to capture any disproportionate likelihood of negative return clusters independently of beta (Zhou and Gao, 2012). Copula functions on the other hand are unable to distinguish between linear dependence and the drivers of disproportionate negative return clusters (Clayton, 1978; Kimeldorf and Sampson, 1975; Patton, 2006, 2009). As a result, our findings help evaluate and improve upon traditional investment management techniques that are focused on managing linear dependence only.

In our analysis of firm characteristics and dependence patterns, we pay particular attention to the role of leverage. Theoretically, the relationship between leverage and equity returns is unambiguous. However, the empirical evidence on the relationship between real estate securities returns and leverage is less clear. That is partly because the relationship between leverage and risk is under-researched. In fact, Giacomini, Ling, and Naranjo (2015) specifically encourage more research on the effect of leverage on the investment performance of real estate securities from the point of view of equity investors. We contribute to this question by examining the relationship between leverage and systematic risk as well as a disproportionate likelihood of negative return clusters with the stock market.

Empirically, we find that linear dependence and an increasing likelihood of return clustering between REITs and stocks are distinct aspects of joint return patterns. Our results suggest that both are significantly related to ex ante observable firm characteristics, but in different ways. Small stocks with low short-term momentum and low turnover are associated with low systematic risk. So are stocks with a high market-to-book ratio and strong long-term momentum. Stocks with strong short-term momentum appear to be at risk of poor return clusters with stocks, while investment growth promotes clustering of positive returns with stocks. We find some evidence that leverage increases linear dependence of REIT returns on stocks in the long run, while our findings strongly suggest that leverage exacerbates clustering of poor returns, with immediate and persistent effect.

Section 2 summarises the related literature. Section 3 develops our testable hypotheses. Section 4 discusses the dependence measures. Section 5 describes method and data. Section 6 presents our empirical findings. Section 7 reports robustness tests. Section 8 concludes. 


\section{Related literature}

Under modern portfolio theory, the benefits of diversification associated with including real estate in a mixed-asset portfolio are typically established on the basis of low average historical correlations (Baum, 2002; Bond, Hwang, Mitchell, and Satchell, 2007; Georgiev, Gupta, and Kunkel, 2003). However, the need to incorporate more complex dependence structures into portfolio selection has been recognised as early as Markowitz (1959). Empirical evidence increasingly points towards time-variation in the benefits of diversification commonly ascribed to real estate. Clayton and MacKinnon (2001) find that the sensitivity of REIT returns to the returns on stocks, bonds and direct real estate varies through time and follows a cyclical pattern. Cotter and Stevenson (2006) report that the correlation between REITs and the stock market fluctuates around a significant positive trend as market integration increases over time. Case, Yang, and Yildirim (2012) provide evidence that structural breaks in the REIT history, such as the introduction of REITs into broader stock market indices, demarcate different correlation regimes.

Time-variation in dependence patterns is partly a function of the prevailing level of volatility in the market. Chong, Miffre, and Stevenson (2009) present evidence that the pairwise correlations between REITs and stocks as well as bonds respond positively to higher volatility in those markets; they find the opposite for the relationships with government securities and commodities. Liow, Ho, Ibrahim, and Chen (2009) extend this analysis to pairs of international listed real estate securities markets as well as the relationships with the corresponding national stock markets. They confirm the positive relationship between conditional correlations of listed real estate securities and stocks and the prevailing level of volatility. These findings suggest that not only are benefits of diversification time-variant, but they also appear to dissipate in periods of higher uncertainty.

The second driver of time-variation in dependence patterns is the strength of the market. Early evidence suggests that REITs exhibit lower systematic risk in bear markets, suggesting that REITs are defensive stocks (Chan, Hendershott, and Sanders, 1990; Glascock, 1991; Glascock and Hughes, 1995; Glascock, Michayluk, and Neuhauser, 2004; Howe and Shilling, 1990). More recently however, a large number of studies report evidence of asymmetric dependence. Many authors find that conditional correlations of listed real estate securities with respect to various benchmarks including stocks, pairs of real estate securities indices, and pairs of listed versus unlisted real estate return indices, in the US and internationally, increase disproportionately more in response to negative return shocks than to positive return shocks (Fei, Ding, and Deng, 2010; Hoesli and Reka, 2013; Liow, 
2012; Michayluk, Wilson, and Zurbruegg, 2006; Yang, Zhou, and Leung, 2012). Moreover, several authors report a disproportionately high likelihood of joint negative return events between pairs of listed real estate market indices and between listed real estate and stocks (Dulguerov, 2009; Goorah, 2007; Hoesli and Reka, 2013; Knight, Lizieri, and Satchell, 2005; Zhou and Gao, 2012), especially following the onset of the sub-prime mortgage crisis in 2007 (Simon and Ng, 2009). These findings suggest that the benefits of diversification commonly associated with investments in real estate securities may be reduced substantially when they are most needed.

In summary, the empirical literature on dependence structures in the returns from listed real estate securities to date has established three stylised facts. Benefits of diversification vary through time, they decrease in periods of higher uncertainty and they also tend to dissipate during bear markets. However, the literature to date has produced limited insight into the fundamental economic drivers of dependence patterns between real estate securities (REITs) and stocks. A notable exception is Liow, Zhou, and Ye (2015), who recognise this gap in the literature and make a significant contribution towards filling it. They study the drivers of quarterly realised correlations between eight international listed real estate securities markets over the period 1995 to 2012. They relate the cross-sectional and time series variation in correlation between markets to a set of market-wide real estate variables including the return on the direct real estate market pairs, pairwise market size and volatility differentials, the influence of the existence of REITs, as well as a set of control variables capturing macroeconomic, stock market, institutional and crisis effects.

Liow, Zhou, and Ye (2015) is the study that is closest to ours. We share the motivating observation that the fundamental economic drivers of dependence patterns are insufficiently understood. However, our work differs from theirs in a number of ways. First, instead of exploring market-wide dependence patterns across pairs of international market indices, we focus on the individual firm level. Second, instead of examining macroeconomic influences on dependence patterns between real estate and stock markets, we focus on the influence of firm fundamentals on the dependence patterns between individual firm returns and the stock market, after controlling for broad real and monetary macroeconomic factors. Finally, instead of studying realised correlations, we focus on the drivers of the CAPM beta, a well-established measure of linear dependence that feeds directly into asset prices, and a novel measure of asymmetric dependence that allows us to explore the drivers of a disproportionate likelihood of joint negative return clusters. To our knowledge, our study is the first to explore the drivers of dependence patterns in the returns from individual real estate securities in this way. 


\section{Hypothesis development}

In our analysis, we focus on the role of leverage in driving the systematic risk of REITs (CAPM beta) and their asymmetric risk of joint negative return clusters with the stock market. Little is know about the relationship between leverage and the risk in equity returns. Sun and Yung (2009) find mixed evidence on the relation between leverage and REIT volatility. Chaudhry, Maheshwari, and Webb (2004) find that leverage drives REIT idiosyncratic risk but the direction of the effect is sensitive to model specification. Against this background, we now develop our testable hypothesis for the expected relationships.

Allen, Madura, and Springer (2000) argue that financial leverage magnifies the firm's equity returns when the return on broader market is positive. Conversely, their argument continues that leverage also magnifies negative returns, creating more pronounced losses. This line of reasoning is consistent with the argument in Goetzmann, Ingersoll, Spiegel, and Welch (2007) that leverage increases the firm's exposure to variation in the return on the general market. As a result, we expect that the sensitivity of a REIT's equity returns to variation in the return on the general market, as measured by linear dependence or systematic risk (CAPM beta), is positively related to the level of leverage of the REIT.

\section{Hypothesis 1: Leverage is positively related to linear dependence (CAPM beta).}

In order to form an expectation of the relationship between leverage and the likelihood of disproportionate joint negative returns with the market, consider managerial incentives for taking risk in a competitive market for investor capital. Diamond and Rajan (2009) describe an incentive for managers to load up on 'hidden' downside risk in the form of tail risk in order to report the compensation as alpha. Goetzmann, Ingersoll, Spiegel, and Welch (2007) identify strategies whereby leverage is used especially for this purpose. Empirical evidence suggests that REIT managers also employ leverage to enhance risk-adjusted performance measures (Alcock, Glascock, and Steiner, 2013). Finally, a typical market decline can quickly precipitate into a severe crash in the presence of levered positions in tail risk due to the financial accelerator effect. The financial accelerator exacerbates the implications of a market decline through tightening credit conditions (Bernanke and Gertler, 1989; Bernanke, Gertler, and Gilchrist, 1996; Kiyotaki and Moore, 1997; Perez-Quiros and Timmermann, 2000). In turn, tighter credit conditions disproportionately affect firms with higher leverage. As a result, we expect that higher leverage increases the firm's risk of experiencing significant negative return clusters with the market.

Hypothesis 2: Leverage is positively related to asymmetric dependence. 


\section{Measuring dependence}

Studying dependence between security returns means describing their joint distribution. The joint distribution of any two random variables can be approximated by a combination of a standard bivariate normal distribution, where dependence is fully captured by linear measures, such as co-variance, or the scaled version, correlation, and a potentially infinite number of higher-order co-moments, such as co-skewness and co-kurtosis. ${ }^{3}$ This perspective on dependence patterns is useful as it allows us to conceptually split dependence into a linear component that informs traditional portfolio management strategies, and the higher-order components that receive increasing academic and investor interest.

The existing literature typically relies on multivariate GARCH models or copula functions. Multivariate GARCH models focus on describing correlations. However, we seek to identify determinants of dependence in a way that is economically meaningful to downside-risk averse investors. Any metric that focuses on a single order of dependence, such as correlation or any related partial moment, will not explore higher-order aspects of dependence. Yet, these are among the major drivers of joint value declines during bear markets (Ang and Chen, 2002; Longin and Solnik, 1995, 2001). ${ }^{4}$ Copula functions on the other hand provide a more comprehensive view on dependence. However, copulas commonly rely on a small number of parameters that simultaneously determine the location, slope and shape of the joint distribution (Clayton, 1978; Kimeldorf and Sampson, 1975; Patton, 2006, 2009). The resulting description may thus be a poor approximation of the true distribution. Further, the parameters of the copula do not map to the individual moments of the joint distribution, and so copulas are unable to distinguish between correlations and any higher-order aspects of dependence. Any copula-based analysis is therefore of limited use in evaluating and improving upon traditional correlation-based diversification strategies.

In order to mitigate the shortcomings of these methods, we study a set of two complementary measures of dependence. First, we examine linear dependence as measured by the CAPM beta, which has established intuitive meaning and is firmly grounded in financial theory. Second, we employ a recently developed measure of asymmetric dependence, the 'Adjusted J statistic'. This measure, along with its economic and statistical motivation, is described in detail in Alcock and Hatherley (2016). In combination, these two measures provide a comprehensive assessment of dependence patterns between security returns. ${ }^{5}$

\footnotetext{
3 This decomposition is commonly referred to as the Edgeworth series expansion. For details, see Hall (1992).

4 Zhou and Gao (2012) provide a lucid discussion of the shortcomings of correlation as a measure of dependence.

5 We could also consider test statistics for structural breaks in dependence patterns. However, tracing test statistics for structural breaks in existing dependence measures does not allow us provide a continuous measure of dependence patterns that can easily be estimated as a function of firm characteristics.
} 
The adjusted $\mathrm{J}$ statistic is designed to capture asymmetric dependence, which is the difference between the dependence of returns on an individual asset and the market across different market states. This metric is derived in the context of Skiadas's (1997a; 1997b) economic framework of disappointment aversion. The Adjusted J statistic is closely related to the J statistic developed by Hong, Tu, and Zhou (2007), which is based on the exceedance correlations between the returns on two assets or portfolios. Longin and Solnik (2001) define the exceedance correlation at level $\vartheta$ as the conditional correlation between two variables when both register shocks of more than $\vartheta$ standard deviations from their means. Under the null hypothesis of no asymmetric dependence, i.e. no significant differences in the exceedance correlations in opposing regions of the joint distribution, the $\mathrm{J}$ statistic is given by:

$$
J_{\rho}:=T\left(\hat{\rho}^{+}-\hat{\rho}^{-}\right)^{\prime} \hat{\Omega}^{-1}\left(\hat{\rho}^{+}-\hat{\rho}^{-}\right) \sim \chi_{N}^{2},
$$

where $\hat{\rho}$ are the exceedance correlations, $T$ is the sample size, $\hat{\Omega}$ is the variance/covariance matrix and $N$ is the number of exceedances. The greater the test statistic, the greater the departure from symmetry. However, the $\mathrm{J}$ statistic does not account for linear dependence and it is unable to indicate the direction of asymmetry. In order to mitigate these shortcomings, Alcock and Hatherley (2016) define the Adjusted J statistic as follows:

$$
J^{A d j}:=\left[\operatorname{sgn}\left(\left[\hat{\rho}^{+}-\hat{\rho}^{-}\right] \mathbf{1}\right)\right] T\left(\hat{\rho}^{+}-\hat{\rho}^{-}\right)^{\prime} \hat{\Omega}^{-1}\left(\hat{\rho}^{+}-\hat{\rho}^{-}\right)
$$

The addition of the sign function (Alcock and Hatherley, 2009) means that the statistic indicates the sign of the sum of the differences between positive and negative conditional correlations and hence indicates the direction of asymmetry. A positive (negative) test statistic indicates net upper (lower) tail dependence. This feature is useful as investors are arguably particularly concerned about lower tail dependence, that is, increasing conditional correlations and thus dissipating benefits of diversification during bear markets. Further, the arguments in the Adjusted J statistic are not the raw or standardised return series but a transformation that controls for the level of linear dependence. ${ }^{6}$ After the transformation, all asset returns display identical betas of unity while the original linear

\footnotetext{
6 The linear component of dependence in any bivariate distribution is captured by the OLS slope coefficient estimator, $\left(X^{T} X\right)^{-1} X^{T} Y$. The adjusted J statistic thus controls for linear dependence by filtering with this estimator. By doing so, the adjusted J statistic controls for the first moment and first co-moment within the Edgeworth expansion of joint returns, ensuring that the adjusted $\mathrm{J}$ captures economically relevant and theoretically motivated information about asymmetric dependence in a statistically rigorous manner. The estimator for the CAPM beta "just happens" to be the same estimator as the OLS beta estimator, and so by filtering through the linear control we are also filtering through the CAPM beta. Filtering through a set of firm-characteristic of macro factors in addition to the CAPM beta might provide additional insights into the role played by these factors and their relationships with asymmetric dependence and thus shed additional light on any return premium generated by these factors. An analysis of this question however requires a structural alteration of the Adjusted J statistic and is therefore beyond the scope of this study. We thank an anonymous referee for pointing this out.
} 
dependence structure between the asset and the benchmark is controlled for. This feature is useful to evaluate and improve upon diversification strategies that traditionally focus only on linear dependence as measured by beta. In summary, the Adjusted J statistic assesses the presence, direction and strength of asymmetric dependence after controlling for linear dependence as measured by the CAPM beta. As a result, the combination of the CAPM beta and the Adjusted J statistic allows us to comprehensively examine linear and higher-order components of dependence patterns separately in a robust manner.

\section{$5 \quad$ Method and data}

\subsection{Empirical approach}

We obtain the dependence measures as follows. We run quarterly firm-level regressions of daily total returns on a stock market benchmark to obtain the single-index (CAPM) beta:

$$
T R_{i t}=\beta_{0}+\beta_{1} \text { Benchmark }_{t}+u_{i t}
$$

where $T R$ is the total return on firm $i$ at day $t$, Benchmark is the total return on the benchmark stock index at time $t, \beta_{0}$ is a constant, $\beta_{1}$ is the regression coefficient we collect from each quarterly regression to generate our first dependent variable, and $u$ is the residual. These quarterly regressions allow us to compile a firm-quarter panel of CAPM beta estimates. In order to obtain a robust estimate of the single-factor beta, we require firms to have more than 50 observations available in a given quarter.

The Adjusted $\mathrm{J}$ statistic is also obtained from daily returns. Recall that the statistic measures exceedance correlations between a firm and the stock market in a given quarter, conditional on the firm and the market experiencing returns $\vartheta$ standard deviations away from their means in that quarter, where $\vartheta$ is a vector of exceedances. We calculate the Adjusted J statistic with exceedances $\vartheta=\{0,0.2,0.4,0.6,0.8,1\}$ in conjunction with the Bartlett kernel for the estimation of the variance-covariance matrix, $\hat{\Omega}$, following Hong, Tu, and Zhou (2007). That means that exceedances are not exogenously defined as a function of economic upturns and downturns, only relative to the quarterly means of daily returns.

Further note that the statistic measures the net difference between corresponding exceedance correlations in opposing tails of the joint distribution. If these net differences are zero, then the joint distribution is symmetrical. If they are different from zero, then the joint distribution is characterised by asymmetric dependence. As a result, the power of the Adjusted J statistic to capture asymmetric dependence is not per se dependent on extreme 
return realisations as would be observed in upturns and downturns only. The ability of the Adjusted $\mathrm{J}$ statistic to detect asymmetric dependence is solely contingent on exceedance correlations in the two opposing tails of the distribution being different from one another.

Lastly, in order to increase the accuracy of the calculation of the Adjusted J statistic, we compute it using one year's worth of daily returns, not one quarter. We thus compile a firm-quarter panel of rolling annual Adjusted J statistics. ${ }^{7}$

We estimate the dependence measures as a function of our chosen set of firm characteristics and macroeconomic control variables, allowing us to assess the marginal impact of a change in any of the firm characteristics on the dependence measures, all else being equal. We estimate the following model using OLS:

$$
\begin{aligned}
& D M_{i t}=\gamma_{0}+\gamma_{1} M L E V_{i, t-1}+\gamma_{2} M B_{i, t-1}+\gamma_{3} \text { LnSize }_{i, t-1}+\gamma_{4} R E T 6_{i, t-1} \\
& +\gamma_{5} R E T 36_{i, t-1}+\gamma_{7} T O_{i, t-1}+\gamma_{8} R E I N V_{i, t-1}+\gamma_{9} R O A E_{i, t-1} \\
& +\gamma_{10} \text { FedFunds } s_{t-1}+\gamma_{11} \text { Rec }_{t}+\gamma_{12} D M_{i t-1}+u_{i t}
\end{aligned}
$$

where $D M$ is the dependence measure, $\gamma_{0}$ is a constant and $u_{i t}$ is the residual. Following the asset pricing literature, we include the following explanatory variables. Market leverage MLEV (Bhandari, 1988) is measured as Total Debt divided by the Market Value of Assets (Total Assets minus Book Equity + Market value of Equity). Firm size LnSize (Banz, 1981; Keim, 1983) is the natural logarithm of the Market Capitalisation. Market-to-book ratio $M B$ (Rosenberg, Reid, and Lanstein, 1985; Stattman, 1980) is the Market Value of Assets divided by the book value of Total Assets. 6-month (36-month) return (RET6 and RET36) (DeBondt and Thaler, 1985; Jegadeesh and Titman, 1993) is the 6-month (36month) cumulative total return. In addition, we control for stock turnover as a measure of liquidity (Acharya and Pedersen, 2005; Holmström and Tirole, 2001; Liu, 2006). The turnover ratio TO is quarterly Trading Volume divided by Common Shares Outstanding. Following the investment-based approach to asset pricing in real estate (Bond and Xue, 2014), we also control for real estate investment growth (REINV) and profitability, measured as return on average equity $(R O A E)$. In order to control for macroeconomic conditions, we include the federal funds rate (FedFunds) and the NBER business cycle indicator as a binary variable that equals one in a recession period $(R e c){ }^{8}$

\footnotetext{
7 The downside of this approach is that we introduce autocorrelation, potentially over four quarters, in the Adjusted $\mathrm{J}$ statistic. However, this is easily remedied by including up to four lags of the Adjusted J statistic in the regression model. Our results are robust to controlling for these additional lags and are available on request.

8 All of our findings are qualitatively equivalent when replacing the policy-determined federal funds rate with a market-determined benchmark bond yield. Results are available on request.
} 
All explanatory variables, except the recession indicator, are lagged by one period. The lag ensures that firm characteristics are observable by market participants prior to the period over which the dependence measure is generated. Consequently, our inference relates to the predictive content of the firm characteristics for the dependence patterns in security returns. The lag also mitigates a potential simultaneous causality bias whereby managers change firm characteristics, for instance by adjusting leverage, in response to observing a given dependence pattern. In order to account for autocorrelation in dependence measures, we include their first lags. We also include property type and quarter fixed effects.

By construction, the dependent variables in (4) are subject to estimation error. Utilising the estimates as the dependent variable in a second-stage regression results in an estimated dependent variable bias. In order to mitigate this bias and enable valid inference, we follow the procedure proposed in Hornstein and Greene (2012) and weight all independent observations by the inverse of the variance of the dependent variable.

The frequency of financial time series observations raises the question of non-synchronous trading and its consequences on the accurate estimation of covariance and related measures of dependence. The phenomenon has been documented as early as Fisher (1966) who demonstrates that when the arrival of trades is random and therefore non-synchronous across assets, then return observations sampled at regular intervals are correlated with neighbouring returns on other assets even when the underlying relationship is purely contemporaneous, leading to a systematic under-estimation of covariance. However, Epps (1979) shows that the bias is severe only beyond the inter-hour level. Considering our daily frequency, we believe that our measurement of covariance is sufficiently accurate.

\subsection{Data set}

We analyse a sample of publicly listed US equity REITs. We collect total return data, firm characteristics and returns on the S\&P500 from SNL Financial. ${ }^{9}$ Apart from firm characteristics, dependence patterns may also be influenced by macroeconomic regimes (Liow, Zhou, and Ye, 2015). We account for macroeconomic conditions using interest rate data and recession indicators. Data on the federal funds rate and the 10-year Treasury is obtained from the Federal Reserve Bank of St Louis's Economic Database. Information on the dates that demarcate macroeconomic regimes are obtained from the NBER.

We begin our analysis in 1993, the beginning of the modern REIT era as marked by the

$\overline{9}$ For robustness, we employ the Russell 2000 small-cap index as an alternative benchmark. Our results remain unchanged and are available upon request. 
introduction of the UPREIT regime. We end the study period in 2013, the most recent full year of data available at the time of writing. Firms enter the sample when they first appear on $S N L$ and leave the sample when they become inactive (acquired or defunct). Firm characteristic data is obtained on a quarterly frequency. Return data for the calculation of the dependence measures is collected on a daily frequency to reduce measurement errors and smoothing of dependence measures. All firm characteristic variables, except the stock returns used to compute the dependence measures, are winsorised at the 1st and 99th percentiles. The final number of firm-quarters is 3,828 from an average of 55 firms per quarter. Figure 2 shows the evolution of the number of sample firms over time.

[Insert Figure 2 about here.]

Table 1 summarises the firm characteristics of the sample REITs. The mean single-factor beta is 0.589 for the $\mathrm{S} \& \mathrm{P} 500$, consistent with the view the REITs are on average defensive stocks (Chan, Hendershott, and Sanders, 1990; Glascock and Hughes, 1995; Howe and Shilling, 1990) and thus implying that REITs offer some benefits of diversification (Baum, 2002; Bond, Hwang, Mitchell, and Satchell, 2007; Georgiev, Gupta, and Kunkel, 2003). The Adjusted J statistic is -0.184 on average, suggesting a slight tendency for REIT returns to cluster disproportionately with poor returns on the stock market.

As for the fundamental firm characteristics, market leverage is on average 0.44 , consistent with the observation that REITs carry significant leverage (Barclay, Heitzman, and Smith, 2013). The mean market-to-book ratio is 1.204 and the mean log of firm size is 12.844 , consistent with the view that REITs are small value stocks (Geltner and Miller, 2001). The 6-month (36-month) cumulative total return averages 0.071 (0.488) over the sample period. On average, a proportion of 0.295 of common REIT shares outstanding is traded each quarter. Investment growth averages 0.185 and profitability averages 0.072 , both broadly consistent with Bond and Xue (2014) who study the role of investment-related factors on asset prices. The federal funds rate averages 0.032 over the study period and a proportion of 0.105 of observations fall into recessionary periods as defined by the NBER. The final column shows the inverse normal z-statistic from a Fisher-type (Augmented Dickey-Fuller) test for unit roots in unbalanced panel data proposed in Choi (2001). The null hypothesis is that all panels (firms) have a unit root in the variable concerned. We reject the null hypothesis for all of the dependence measures and all but one of the firm characteristics we are interested in (firm size). We conclude that concerns around nonstationarity of the variables in our study are negligible.

[Insert Table 1 about here.] 
Figure 3 Panel (a) shows the evolution of quarterly mean firm-level single-factor beta estimates with respect to the S\&P500 over time. From approximately 1995 onwards, the average REIT beta increases at a slow but steady pace over time, consistent with the view of increasing market integration that has been observed for international real estate and stock market indices (Liow, Zhou, and Ye, 2015). The measure then increases sharply surrounding the global financial crisis of $2007 / 08$, consistent with the anecdotal observation that in a crisis, correlations approach one (Gordon, 2009). Single-factor beta estimates were also significantly more volatile during the crisis than during the remainder of the study period. Further, the $95 \%$ confidence interval around the mean estimate is larger at the beginning of the sample period from 1993 to 1995, then reduces to around 25 basis points until 2004, after which it widens. Confidence intervals are wider especially during the crisis and reduce gradually thereafter, consistent with our expectation of cross-sectional variation in the sensitivity to stock market returns and thus benefits of diversification.

Figure 3 Panel (b) shows the evolution of quarterly mean firm-level Adjusted J statistic estimates with respect to the S\&P500. For most of the study period from 1993 to approximately 2005, the mean Adjusted J statistic oscillates with a cyclical pattern between zero and -1, suggesting no to slight levels of clustering of negative returns. Between 2005 and 2006, the peak of the boom prior to the global financial crisis of $2007 / 08$, the average Adjusted J statistic becomes increasingly positive reaching a peak of approximately 1.5, suggesting disproportionate clustering of positive returns during this significant expansion phase for REITs. The measure then drops sharply. After the end of the global financial crisis of 2007/08, the mean Adjusted J statistic resumes its pre-crisis levels and cyclical pattern. Consistent with beta, the $95 \%$ confidence interval around the mean estimate is larger at the beginning of the sample period and then reduces slightly over time. However, confidence intervals around the mean Adjusted J statistic are consistently wider than for the CAPM beta, suggesting cross-sectional variation no only in average linear dependence but even more so in the disproportionate tendency to register joint negative returns with the stock market.

[Insert Figure 3 about here.]

Figure 4 traces the evolution of the mean CAPM beta and Adjusted J statistic measures relative to NBER recession dates. The downturn in 2001 was not associated with any visible variation in the dependence measures marking the beginning or the end of this episode. However, in the recession 2007-2009, we notice two trends. First, the CAPM beta increases significantly from Q1 2008 onwards until it peaks in Q1 2009 and subsequently 
returns to pre-crisis levels. Second, the Adjusted J statistic declines substantially from approximately 2006 onwards and hits a trough at the beginning of the crisis at the end of 2007. It then undergoes some fluctuation during the crisis period and eventually returns to pre-crisis levels. That means that the Adjusted J statistic dropped markedly a number of quarters before the official onset of the global financial crisis of 2007/08 of 2007-2009 that saw severe joint losses across asset classes including stocks and real estate securities (Gordon, 2009). This observation suggests that the measure has predictive power for future REIT performance that managers, investors and policy makers may monitor.

[Insert Figure 4 about here.]

\section{Results}

\subsection{Unconditional analysis}

Table 2 describes the relationships between firm characteristics and dependence measures using simple pairwise correlations. We find that, on an unconditional basis, the single-factor beta (S\&P500) is slightly positively related to the Adjusted J statistic. The Adjusted J statistic is calculated based on filtered returns in order to avoid confounding the measurement of asymmetric dependence with linear dependence. Any remaining correlation between the two measures thus suggests that there are genuinely common drivers.

Overall, the top three covariates of both dependence measures are the interest rate, turnover, firm size. In relative terms, we find that linear dependence, as measured by the single-factor CAPM beta, is related to macroeconomic factors and firm characteristics to a similar degree. Asymmetric dependence is more strongly related to firm characteristics, especially size, while the relationship with macroeconomic factors is relatively weaker. In conclusion, we find that firm characteristics matter for linear dependence and are also related to an increasing likelihood of joint negative returns between REITs and stocks.

[Insert Table 2 about here.]

Next, we carry out an unconditional multivariate quintile analysis. Every quarter, we sort firms into quintiles according to their beta estimate and, separately, according to their Adjusted J statistic, both relative to the S\&P500 index. Quintile 1 contains the firm-quarters with the lowest values of the dependence measure. Quintile 5 contains the firm quarters with the highest values for the dependence measures. We tabulate the corresponding mean firm characteristics in each quintile and then test the hypothesis that these means differ 
significantly across the top and bottom quintiles. This analysis allows us to identify the set of characteristics that firms with low systematic risk and, respectively, a low tendency for negative return clusters with the stock market, have in common.

[Insert Table 3 about here.]

For the analysis of the CAPM beta in Panel (a) of Table 3, the most defensive stocks are in quintile 1 (lowest beta measure). The most defensive stocks have a number of characteristics in common. They are simultaneously small, high-growth (high book-tomarket ratio) firms that are less intensively traded. In contrast to the pairwise correlation analysis, we find no evidence that the difference in leverage is part of the characteristics that significantly distinguish low-beta from high-beta stocks.

In Panel (b) of Table 3, the stocks with the highest likelihood of joint negative return clusters with stocks are in quintile 1 (lowest Adjusted J statistic). The stocks with the highest tendency to display lower tail dependence with the stock market also have number of characteristics in common. They are on average small and thinly traded. This unconditional observation suggests a trade-off between linear dependence and the likelihood of disproportionate joint negative return clusters. While small size and thin trading activity appear to be associated with low linear dependence, they simultaneously exacerbate asymmetric joint declines with the stock market. The second difference to the analysis of the CAPM beta is the role of leverage. In this multivariate setting, we find that leverage is significantly associated with a higher likelihood of joint negative return clusters. In other words, we find that leverage is not one of the characteristics that significantly distinguishes defensive stocks that exhibit a low degree of dependence on the stock market on average. However, our findings do suggest that the level of indebtedness of a firm significantly exacerbates the likelihood of disproportionate joint negative returns. As a result, our finding suggests that leverage has an asymmetric impact on performance.

\subsection{Firm characteristics and average systematic risk}

Table 4 presents the regression results for the CAPM beta with respect to the S\&P500. Our model explains $71 \%$ of the total variation in firm-level beta estimates in the full sample of 3,828 observations over the study period 1993-2013. The estimation for the recession period contains significantly fewer observations than the non-recession period (401 versus $3,427)$. However, the explanatory power of our model is higher in the recession period (0.87) than in the non-recession period (0.67). 
[Insert Table 4 about here.]

We do not find evidence for a relationship between leverage and systematic risk in our one-period ahead regressions. This finding stands in contrast to our first hypothesis. In theory, leverage increases the sensitivity of the return on equity to variation in the return (Goetzmann, Ingersoll, Spiegel, and Welch, 2007). Empirically, we find a positive sign of the coefficient on leverage, which is intuitive, but the value of the coefficient is not statistically significant. However, the impact of leverage does pass the threshold for statistical significance in the longer run: When we consider the two-period (6 months) ahead measure of beta, we find evidence consistent with the hypothesis that leverage increases average systematic firm risk (see Column (1) in Appendix A.1). Our finding is thus also consistent with the earlier work of Allen, Madura, and Springer (2000).

As for the remaining firm characteristics, we find a number of additional significant relationships. First, we find that beta is positively related to firm size. Our finding seems intuitive. Larger firms have a larger share of the market return and are thus more sensitive to market variation. This finding is robust across the different sub-periods and the coefficient is stable with an economic impact of approximately 7 basis points on beta for a one standard deviation increase in logged firm size.

We also find that beta is inversely related to the market-to-book ratio. This finding suggests that firms with stronger growth opportunities are less sensitive to variation in the market return, implying that these growth opportunities are largely idiosyncratic and thus shift the total risk of the firm away from exposure to variation in the market. Further, the effect of growth opportunities on beta is numerically almost three times larger in the recessionary sub-period, suggesting that idiosyncratic growth opportunities were especially valuable during this period of general market turmoil. The economic impact of a one standard deviation drop in the market-to-book ratio is an increase in beta by 2 basis points in the full study period, and 5 basis points in the recession period.

Our evidence for the relationship between momentum and beta is mixed. 6-month returns are positively related to beta in the full and non-recessionary periods, while 36-month returns are inversely related to beta in these periods. The reversal in the effects of shortand long-term momentum suggests that long-term cumulative returns reflect performance that is unrelated to the performance of the underlying market, but driven by idiosyncratic factors. Short-term performance may be more driven by short-term trading activity, increasing systematic risk. These effects disappear in the recession periods, suggesting that their influence on systematic risk is more relevant in benign market environments. In the 
full period, the economic impact of a one standard deviation increase in short-term momentum, or an equivalent reduction in long-term momentum, is an increase of approximately 1 basis point in the single-index beta coefficients, respectively. Our finding is consistent with the literature on momentum and momentum-reversal (DeBondt and Thaler, 1985).

Our results suggest that the turnover ratio, i.e. the proportion of shares outstanding that is traded in a quarter, is positively related to beta. As a stock is traded more frequently, the sensitivity of its performance to the return on the mark increases. Frequent trading may be a signal of investors seeking short-term gains by following momentum, rather than investing for the long run on the basis of the fundamentals of the firm, thus linking the findings on momentum and trading volume. On average, the economic impact of a one standard deviation increase in turnover is an 8 basis points increase in systematic risk.

We find that beta estimates are significantly related to macroeconomic factors. ${ }^{10}$ This finding echoes our earlier observation that there is a significant negative unconditional correlation between interest rates and the systematic risk of REITs, and that systematic risk increased in recession periods. However, our findings also suggest that while macroeconomic factors may provide some guidance on the systematic risk of REITs, they are unable to supersede fundamental firm characteristic factors. In other words, our findings suggest that while the systematic risk of all REITs to some extent is influenced by macroeconomic conditions, REITs with the appropriate fundamental characteristics, such as smaller size and higher (idiosyncratic) growth opportunities are able to withstand these conditions better and maintain lower systematic risk in a recession than others.

We find a significant relationship between past values of beta and present values of beta, as the lag of beta is positive and significant in our regression results. However, while the recent history of systematic risk is a significant indicator of the present level of systematic risk, it does not replace or subsume the effect of fundamental and macroeconomic factors.

In summary, our results suggest that investors are able to form expectations about the average sensitivity of a firm's equity to variation in the return on the market, and thus the benefits of including a given stock in a portfolio, by assessing the firm's size and growth opportunities, its past performance and the intensity with which it is traded. Even in recession periods, the firm fundamentals size, market-to-book ratio and trading intensity maintain significant predictive power for firm-level systematic risk.

\footnotetext{
$\overline{10}$ Our findings are consistent across the policy rate (federal funds rate) and the market-determined interest rate (10-year Treasury rate).
} 


\subsection{Firm characteristics and negative return clusters}

Table 5 presents the regression results for the Adjusted J statistic with respect to the S\&P500. Our model explains 58\% of the total variation in firm-level Adjusted J statistic estimates in the full sample.

[Insert Table 5 about here.]

Consistent with our second hypothesis, we find that leverage is inversely related to Adjusted J statistic. A lower statistic implies a higher likelihood of negative return clusters with the market, suggesting that leverage disproportionately exacerbates the risk of a joint decline in the returns on REITs and the stock market. Over the full period, the economic impact of a one standard deviation increase in leverage is a 2 basis points drop in the Adjusted J statistic, i.e. a $10 \%$ decline relative to the sample mean of the Adjusted J statistic. In the recessionary period, the economic impact increases to a 10 basis points drop in the Adjusted J statistic for a one standard deviation increase in leverage. In combination with our analysis of the CAPM beta, our results suggest that, while leverage may not substantially increase the one-period ahead estimate of systematic risk of REITs on average, it has a statistically and economically significant impact on the risk of joint negative return clusters between REITs and the stock market.

Understanding the link between leverage and systematic risk as well as asymmetry risk is useful for identifying the mechanism through which leverage affects equity returns. In theory, the relationship between leverage and equity returns is clear. According to the second proposition of the seminal work by Modigliani and Miller $(1958,1963)$, leverage increases the risk to equity holders as residual claimants and thus higher leverage is associated with higher rates of required return on equity.

However, the empirical evidence on the relationship between leverage and equity returns is less clear. Over the period 1994-2003, Cheng and Roulac (2007) document a weak inverse relationship between REIT returns and leverage. Sun, Titman, and Twite (2015) focus on the global financial crisis of 2007/08 and present evidence that more highly levered REITs suffered larger declines in that period than their less indebted counterparts. In an international sample of listed real estate investment firms, Pavlov, Steiner, and Wachter (2015) find that leverage is unrelated to stock returns. Ling and Naranjo (2015) document significant time-variation in the relationship between leverage and REIT returns as well as volatility, with more highly levered REITs experiencing more pronounced variation in stock returns through the market cycle. Giacomini, Ling, and Naranjo (2015) on the other 
hand find a positive relationship between international real estate securities returns and leverage. Their evidence also suggests that the relationship between returns and leverage was negative during the global financial crisis of 2007/08.

The studies mentioned above do not address the way in which leverage affects risk, and are thus unable to document the mechanism through which leverage affects the return on equity that investors receive as compensation for the risk they assume. Our results suggest that leverage affects equity returns primarily through the increased risk of joint negative return clusters with the market, and to some extent also through higher systematic risk as measured by the CAPM beta. Our finding may help explain some of the inconclusive evidence on the impact of leverage on performance by highlighting the asymmetric nature of its effect on dependence patterns in REIT returns.

Recall that the economic magnitude of the effect of leverage also increases substantially during the recessionary sub-period. As a result, our finding further adds to the empirical evidence on the short-term and long-term detrimental effects of leverage on REIT performance during and after the financial crisis of 2008 that is documented in Sun, Titman, and Twite (2015) and in Giacomini, Ling, and Naranjo (2015).

Leverage may influence returns through a tax shield effect, an effect on the cost of equity capital directly, or an indirect effect via the cost of debt capital. For tax-exempt REITs the tax effect is nearly irrelevant. The debt capacity of real estate assets (Cvijanović, 2014; Giambona, Golec, and Schwienbacher, 2014) allows REITs to pledge collateral when sourcing debt. The use of collateral is often associated with better credit outcomes ${ }^{11}$, suggesting the REIT cost of debt has a relatively lower sensitivitiy to leverage. This leaves the cost of equity channel. The literature suggests that leverage indeed influences REIT stock returns, and thus the cost of equity. However, Giacomini, Ling, and Naranjo (2015) note that the evidence on the average strength and direction of the effect is unclear. Our work suggests that a focus on the effect of leverage on asymmetry risk helps identify a clear inverse relationship between realised REIT returns and leverage.

We find that the Adjusted J statistic is positively related to firm size, suggesting a tradeoff between average systematic risk and the risk of disproportionate joint return clusters in this respect. We find that larger firms carry higher systematic risk but that they are less likely to exhibit joint negative return clusters with stocks, suggesting that they hold portfolios which are more robust to downturns. This finding implies that stock selection

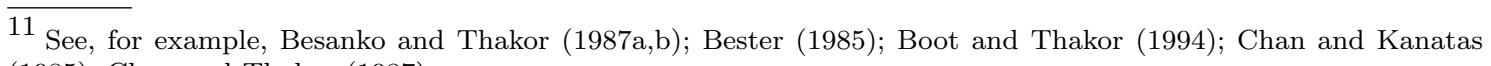
(1985); Chan and Thakor (1987) 
according to firm size has to be sensitive to the expected market environment in order to make an effective contribution to portfolio management. In economic terms, as the log of firm size increases by one standard deviation, the Adjusted J statistic increases by 5 basis points, or $20 \%$ relative to the mean Adjusted J statistic in the full sample.

The evidence we find for the relationship between past (6-month and 36-month) returns and the Adjusted $\mathrm{J}$ statistic is consistent with the evidence for systematic risk on average in the full study period. Strong short-term momentum is associated with a drop in the Adjusted J statistic, i.e. it exacerbates a stock's tendency to exhibit joint negative return clusters with the market. On the other hand, strong long-term momentum is associated with an increase in the Adjusted $\mathrm{J}$ statistic, suggesting that it alleviates the risk of joint negative return clusters with the stock market.

We find that the estimates of the Adjusted $\mathrm{J}$ statistic are less strongly related to the macroeconomic factors. ${ }^{12}$ This finding reflects our earlier observation that the pairwise correlations between firm characteristics and the Adjusted J statistic are relatively stronger than those with the macroeconomic variables.

In contrast to the analysis of beta, we find a significant relationship between real estate investment growth and the risk of joint negative return clusters. As investment growth increases, the likelihood of joint negative return clusters is reduced significantly. Our finding adds to the literature on the relevance of investment-related factors to REIT assets prices by establishing a link between those factors and asymmetry risks (Bond and Xue, 2014).

We also find evidence that there is a significant relationship between past values of beta and present values of the Adjusted J statistic, as the lag of beta is positive and significant in our regression results. However, while the recent history of systematic risk is a significant indicator of the present level of asymmetry risk, it does not replace or subsume the effect of fundamental and macroeconomic factors. The same is true for the lag of asymmetry risk itself. While our findings suggest a significant trend component in this measure, the firm characteristics are still statistically and economically meaningful predictors of the risk of joint negative return clusters between a REIT and the stock market.

In summary, our results suggest that investors are able to form expectations about the risk of a REIT to exhibit negative return clusters with the market, and thus the benefits of including a given stock in a portfolio, by assessing the firm's leverage, size as well as its

$\overline{12}$ Our findings are consistent across the policy rate (federal funds rate) and the market-determined interest rate (10-year Treasury rate). 
investment growth and past performance. During recession periods, the most important predictors of a firm's likelihood to register joint return declines with the market are its leverage and investment growth metrics. Our findings are generally robust to a longer-term prediction horizon as well (see Column (2) in Appendix A.1).

\section{Robustness tests}

In our main analysis, we have winsorised firm characteristics and dependence measures to mitigate any undue influence of outliers. However, winsorising may lead us to underestimate the true magnitude of the effects. For robustness, we have conducted two additional tests: (i) We have run our main regression analysis with only the firm characteristic variables winsorised but not the dependence measures; (ii) We have run our regression analysis with no variables winsorised at all. The results are qualitatively identical.

However, the coefficient estimates increase in magnitude in the two additional tests (see example for leverage in Table 6). Overall, these additional findings suggest that our main results are conservative and indicate the lower bound on the leverage effect.

[Insert Table 6 about here.]

We have estimated the regressions of the CAPM beta and the Adjusted J statistic on the basis of the implicit assumption that they are independent. However, in order to account for the possibility of cross-equation correlation of residuals, we reproduce our main regression results for the full study period using Seemingly Unrelated Regressions (SUR, Zellner (1962, 1963); Zellner and Huang (1962)). The results from this robustness test in Table 7 show that our findings are identical. That is because the model for the CAPM beta is nested in the model for the Adjusted J statistic. The SUR framework also allows for joint hypothesis tests. We exploit this feature to test a joint hypothesis about the influence of leverage on both dependence measures. We reject the hypothesis $\left(\chi^{2}=5.50\right.$, $\mathrm{p}$-value $=0.064)$ that leverage is jointly zero in both models, confirming the influence of leverage on dependence patterns that we have documented in the single-equation models.

[Insert Table 7 about here.]

Our suggested intuition behind the asymmetric effect of leverage on dependence patterns is based on managerial incentives to increase exposure to hidden tail risks, possibly via leverage (Alcock, Glascock, and Steiner, 2013; Goetzmann, Ingersoll, Spiegel, and Welch, 2007), and report the compensation as alpha (Diamond and Rajan, 2009). Our argument 
then implies that this strategy is unsuccessful and that leverage mainly filters through to asymmetric and linear dependence, not alpha. In order to examine this point empirically, we exploit the following convenient feature of our empirical set-up. The estimation of the CAPM beta allows us to obtain a value for alpha as a measure of performance that is unrelated to the firm returns generated as compensation for the linear dependence of the firm on the variation in the return on the market. We collect a firm-quarter panel of alpha estimates analogous to the way in which we compile the beta estimates. We then regress these alpha estimates on leverage and the firm characteristics of interest in our study. The results shown in Table 8 suggest that leverage is indeed unrelated to alpha, implying that strategies of using leverage to increase tail risk exposure are unable to improve alpha. This finding lends additional support to our earlier result that leverage primarily increases asymmetric and in the longer run also linear dependence.

[Insert Table 8 about here.]

Mosteller (1977) argues that conventional linear regression techniques solely describe the conditional mean of a response variable and as such often provide an incomplete picture. In order to provide a more comprehensive picture of the relationship between firm characteristics and dependence patterns, we estimate a quantile regression of the conditional median of the dependence measures (Bassett and Koenker, 1978; Koenker, 2005; Koenker and Bassett, 1978). The results shown in Table 9 suggest that our main finding of the effect of leverage on asymmetric dependence is robust when estimating the conditional median of the Adjusted J statistic instead of its conditional mean. Furthermore, the results reveal a contemporaneous effect of leverage on linear dependence as measured by the conditional median of the CAPM beta as well. Our finding suggests that the weaker relationship between leverage and the conditional mean of the CAPM beta may be driven by the effect of outliers, as the mean is more sensitive to outliers than the median of a distribution. This observation further underpins our argument that our main findings are conservative and represent a lower bound on the effect of leverage on dependence patterns.

\section{[Insert Table 9 about here.]}

Our analysis mainly considers characteristics pertaining to the general and financial structure of the firm. However, REITs are also distinguished along the property sector that they focus on. The nature of the underlying assets and associated lease contracts that is specific to any given property sector may also influence dependence patterns. Therefore, we have recovered the coefficients on the sector fixed-effects we include in our empirical specifications. Table 10 shows that these are largely insignificant. The only exceptions are 
multi-family housing and specialty properties, which have slightly lower levels of linear dependence. We conclude from this robustness test that the influence of firm characteristics is statistically and economically more important for determining dependence patterns than the nature of the underlying assets. This observation implies that investors and managers in all REIT sectors may benefit from understanding the role of firm characteristics and especially leverage in driving the dependence profile of their firms.

[Insert Table 10 about here.]

For robustness, we have also considered measures of return synchronicity obtained as the $R^{2}$ coefficients of quarterly single-index CAPM regressions of the firm returns relative to the S\&P500 index (Chan and Chan, 2014; Cotter, Gabriel, and Roll, 2015; Han, Hwang, and Cho, 2015; Roll, 1988). Table 11 shows the results.

[Insert Table 11 about here.]

With regards to our central hypothesis on leverage, the results suggest that firms with higher levels of leverage have lower return synchronicity with the S\&P500 index in the sense that the variation in the returns on that stock market index has lower explanatory power for the returns on the firm. This robustness test suggests that, for a given level of total risk, leverage shifts a portion of that total risk away from the linear, symmetric exposure to variation in the stock market, and towards higher-order components of risk that are not captured in standard linear measures. Therefore, this finding is consistent with our main result that leverage primarily increases asymmetry risks in REIT firm returns.

Lastly, the principles of corporate finance state that leverage magnifies both positive and negative returns on the firm's equity. These principles imply that when negative returns are realised, as in a recession, then we should anticipate a lower Adjusted J statistic. It follows that if the influence of leverage is symmetrical, then we would anticipate a higher positive Adjusted J statistic in times of economic expansion. However, our argument implies an asymmetric influence of leverage, affecting the downside disproportionately more than the upside. In order to illustrate the asymmetric effect of leverage further, we estimate positive and negative return clusters separately by focusing on positive and negative observations of the Adjusted J statistic as distinct from one another. As expected, we only find that leverage exacerbates the likelihood of joint negative returns. We do not find evidence that leverage promotes the occurrence of joint positive returns on the upside, supporting our argument that leverage has a disproportionate effect on the downside. 
[Insert Table 12 about here.]

\section{Conclusion}

The literature suggests that the fundamental economic drivers behind firm-level systematic risk as well as the risk of joint negative returns between a REIT and the stock market are insufficiently understood. In particular, the role of leverage in determining dependence patterns is under-researched. Understanding this link is important in order to identify the channels through which leverage affects risk and thus returns on REIT stocks. To the best of our knowledge, our study is the first to explore the fundamental REIT firm characteristics that determine these aspects of dependence patterns in REIT returns.

We find that linear dependence and an increasing likelihood of return clustering between REITs and stocks are distinct aspects of return patterns. We find strong relationships between firm fundamentals and systematic risk as well as asymmetric risk that are unexplained by macroeconomic events, monetary policy regimes or trends in the risk measures themselves. While the influence of firm characteristics is somewhat reduced during recessionary periods, they remain significant. However, average systematic risk and asymmetric risk are related to firm characteristics in different ways.

Specifically, stocks with low systematic risk are typically small, with low short-term momentum, low turnover, high growth opportunities and strong long-term momentum. In order to reduce risk of negative returns clusters, robust portfolios should underweight stocks with strong short-term momentum. On the other hand, investment growth is associated with a lower likelihood of joint negative return clusters. Lastly, we find some evidence that leverage increases linear dependence of REIT returns on stocks in the longer run, but has an asymmetric impact and significantly exacerbates clustering of poor returns in the short and longer term. This last finding adds to the evidence on the role of leverage in REIT performance by highlighting the asymmetric nature of leverage on risk.

The practical implications of understanding the drivers of dependence patterns are profound. Our results help guide managers in modulating the investment risk of their firm, for instance by choosing the appropriate level of leverage for their firm. On the other hand, our findings also provide guidance for investors. Our results imply that investors are able to draw valid inferences about the future systematic and asymmetric risk profile of a REIT from observable firm characteristics. Overall, our findings assist managers and investors alike in assessing and managing the role of REIT stocks in mixed-asset portfolios. 
We see two avenues for future research on this topic. The first relates to how investors can modify traditional diversification strategies to account for asymmetry risks as measured by the Adjusted J statistic, above and beyond the linear dependence captured in the familiar CAPM beta. Research efforts in stocks already present promising results. Hatherley and Alcock (2007) and Alcock and Hatherley (2009) develop a general methodology that can be used to determine the robustness of mean-variance-based portfolio theory to nonnormal assumptions, focusing particularly on the effects of the assumption of asymmetric dependence. They demonstrate that for both portfolios of indices and for individual stocks, portfolio performance substantially improves by correcting for asymmetric dependence. At this stage, however, little definitive can be said about the effects of asymmetric dependence on the optimal real estate portfolio. Second, there is the question of pricing asymmetry risks. Again, initial results for general stocks (Alcock and Hatherley, 2016) suggest a significant price premium for stocks with low risk of disproportionate negative return clusters, and a significant price discount for stocks with high risk of disproportionate negative return clusters. Yet, research has yet to establish the price of asymmetric dependence in real estate and listed real estate securities. While these questions are beyond the scope of this study, they may provide fruitful ground for future research. 


\section{References}

Acharya, V. V., And L. H. Pedersen (2005): "Asset pricing with liquidity risk," Journal of Financial Economics, 77(2), 375-410.

Alcock, J., J. Glascock, and E. Steiner (2013): "Manipulation in U.S. REIT Investment Performance Evaluation: Empirical Evidence," Journal of Real Estate Finance and Economics, 47(3), 434-465.

Alcock, J., AND A. Hatherley (2009): "Asymmetric dependence between domestic equity indices and its effect on portfolio construction," Australian Actuarial Journal, $15(1), 143-180$.

(2016): "Characterising the Asymmetric Dependence Premium," Review of Finance, Forthcoming.

Allen, M. T., J. Madura, And T. M. Springer (2000): "REIT Characteristics and the Sensitivity of REIT Returns," Journal of Real Estate Finance and Economics, 21(2), $141-152$.

Ang, A., And G. BeKaert (2002): "International Asset Allocation with Regime Shifts," Review of Financial Studies, 15(4), 1137-1187.

Ang, A., AND J. Chen (2002): "Asymmetric correlations of equity portfolios," Journal of Financial Economics, 63(3), 443-494.

Ang, A., J. Chen, And Y. Xing (2006): "Downside Risk," Review of Financial Studies, 19(4), 1191-1239.

BANZ, R. W. (1981): "The relationship between return and market value of common stocks," Journal of Financial Economics, 9(1), 3-18.

Barclay, M. J., S. M. Heitzman, And C. W. Smith (2013): "Debt and taxes: Evidence from the real estate industry," Journal of Corporate Finance, 20(0), 74-93.

Bassett, Gilbert, J., And R. Koenker (1978): "Asymptotic Theory of Least Absolute Error Regression," Journal of the American Statistical Association, 73(363), 618-622.

Baum, A. (2002): Commercial Real Estate Investment. Estates Gazette.

Bernanke, B., And M. Gertler (1989): "Agency Costs, Net Worth, and Business Fluctuations," American Economic Review, 79(1), 14-31.

Bernanke, B., M. Gertler, And S. Gilchrist (1996): "The Financial Accelerator and the Flight to Quality," Review of Economics and Statistics, 78(1), 1-15.

Besanko, D., And A. V. Thakor (1987a): "Collateral and Rationing: Sorting Equilibria in Monopolistic and Competitive Credit Markets," International Economic Review, 28(3), 671-689.

Besanko, D., And A. V. Thakor (1987b): "Competitive equilibrium in the credit market under asymmetric information," Journal of Economic Theory, 42(1), 167-182.

Bester, H. (1985): "Screening vs. Rationing in Credit Markets with Imperfect Information," American Economic Review, 75(4), 850-855.

BHANDARI, L. C. (1988): "Debt/equity ratio and expected common stock returns: empirical evidence," Journal of Finance, 43(2), 507-528.

Bond, S., And C. Xue (2014): "The Cross Section of Expected Real Estate Returns: Insights from Investment-Based Asset Pricing," PREA-RERI Working Paper.

Bond, S. A., S. Hwang, P. Mitchell, and S. SAtchell (2007): "Portfolio allocation in the modern world," IPF Research Report.

Boot, A. W. A., And A. V. Thakor (1994): "Moral Hazard and Secured Lending in an Infinitely Repeated Credit Market Game," International Economic Review, 35(4), 899-920.

Case, B., Y. Yang, And Y. Yildirim (2012): "Dynamic Correlations Among Asset Classes: REIT and Stock Returns," Journal of Real Estate Finance and Economics, 
44(3), 298-318.

Chan, K., AND Y.-C. Chan (2014): "Price informativeness and stock return synchronicity: Evidence from the pricing of seasoned equity offerings," Journal of Financial Economics, 114(1), 36-53.

Chan, K. C., P. H. Hendershott, And A. B. Sanders (1990): "Risk and return on real estate: Evidence from equity REITs," AREUEA Journal, 18(4), 431-452.

Chan, Y.-S., AND G. Kanatas (1985): "Asymmetric Valuations and the Role of Collateral in Loan Agreements," Journal of Money, Credit and Banking, 17(1), 84-95.

Chan, Y.-S., And A. V. Thakor (1987): "Collateral and Competitive Equilibria with Moral Hazard and Private Information," Journal of Finance, 42(2), 345-363.

Chaudhry, M., S. Maheshwari, And J. Webb (2004): "REITs and idiosyncratic risk," Journal of Real Estate Research, 26(2), 207-222.

Cheng, P., And S. E. Roulac (2007): "REIT Characteristics and Predictability," International Real Estate Review, 10(2), 23-41.

Chor, I. (2001): "Unit root tests for panel data," Journal of International Money and Finance, 20(2), 249-272.

Chong, J., J. Miffre, And S. Stevenson (2009): "Conditional correlations and real estate investment trusts," Journal of Real Estate Portfolio Management, 15(2), 173-184.

Clayton, D. (1978): "A model for association in bivariate life tables and its application in epidemiological studies of family tendency in chronic disease incidence," Biometrika, 65(1), 141-151.

Clayton, J., And G. MacKinnon (2001): "The time-varying nature of the link between REIT, real estate and financial asset returns," Journal of Real Estate Portfolio Management, 7(1), 43-54.

Cotter, J., S. Gabriel, And R. Roll (2015): "Can Housing Risk Be Diversified? A Cautionary Tale from the Housing Boom and Bust," Review of Financial Studies, 28(3), 913-936.

Cotter, J., And S. Stevenson (2006): "Multivariate modelling of daily REIT volatility," Journal of Real Estate Finance and Economics, 32(3), 305-325.

Cvijanović, D. (2014): "Real Estate Prices and Firm Capital Structure," Review of Financial Studies, 27(9), 2690-2735.

DeBondt, W. F. M., And R. Thaler (1985): "Does the Stock Market Overreact?," Journal of Finance, 40(3), 793-805.

Diamond, D. W., And R. G. Rajan (2009): "The Credit Crisis: Conjectures about Causes and Remedies," American Economic Review, 99(2), 606-10.

Dulguerov, M. (2009): "Real estate and portfolio risk: an analysis based on copula functions," Journal of Property Research, 26(3), 265-280.

Epps, T. W. (1979): "Comovements in Stock Prices in the Very Short Run," Journal of the American Statistical Association, 74(366), 291-298.

Fei, P., L. Ding, And Y. Deng (2010): "Correlation and volatility dynamics in REIT returns: Performance and portfolio considerations," Journal of Portfolio Management, $36(2), 113-125$.

Fisher, L. (1966): "Some New Stock-Market Indexes," Journal of Business, 39(1), 191225.

Geltner, D. M., And N. G. Miller (2001): Commercial Real Estate Analysis and Investments. Prentice Hall.

Georgiev, G., B. Gupta, And T. Kunkel (2003): "Benefits of real estate investment," Journal of Portfolio Management, 29(5), 28-33.

Giacomini, E., D. C. Ling, And A. Naranjo (2015): "Leverage and Returns: A CrossCountry Analysis of Public Real Estate Markets," Journal of Real Estate Finance and 
Economics, 51(2), 125-159.

Giambona, E., J. Golec, And A. Schwienbacher (2014): "Debt Capacity of Real Estate Collateral," Real Estate Economics, 42(3), 578-605.

GLASCOCK, J. L. (1991): "Market conditions, risk, and real estate portfolio returns: Some empirical evidence," Journal of Real Estate Finance and Economics, 4(4), 367-373.

Glascock, J. L., AND W. T. Hughes (1995): "NAREIT identified exchange listed REITs and their performance characteristics: 1972-1991," Journal of Real Estate Literature, 3(1), 63-83.

Glascock, J. L., D. Michayluk, and K. Neuhauser (2004): "The riskiness of REITs surrounding the October 1997 stock market decline," Journal of Real Estate Finance and Economics, 28(4), 339-354.

Goetzmann, W., J. Ingersoll, M. Spiegel, and I. Welch (2007): "Portfolio Performance Manipulation and Maipulation-Proof Performance Measures," Review of Financial Studies, 20(5), 1503-1546.

Goorah, A. (2007): "Real estate management with copulas," Journal of Property Research, 24(4), 289-311.

GoRDOn, J. (2009): "The global financial crisis and international property performance," Wharton Real Estate Review, 13, 74-80.

Hall, P. (1992): The bootstrap and Edgeworth expansion. Springer, New York.

Han, J., M. Hwang, And M. Cho (2015): "Credit Constraint and Housing Price Synchronicity: Evidence from the LTV Regulation in Korea," Working Paper.

Hatherley, A., AND J. AlCOCK (2007): "Portfolio construction incorporating asymmetric dependence structures: A user's guide," Accounting and Finance, 47(3), 447-472.

Hoesli, M., AND K. ReKA (2013): "Volatility Spillovers, Comovements and Contagion in Securitized Real Estate Markets," Journal of Real Estate Finance and Economics, $47(1), 1-35$.

Holmström, B., And J. Tirole (2001): "LAPM: A Liquidity-Based Asset Pricing Model," Journal of Finance, 56(5), 1837-1867.

Hong, Y., J. Tu, AND G. ZhOU (2007): "Asymmetries in stock returns: Statistical tests and economic evaluation," Review of Financial Studies, 20(5), 1547-1581.

Hornstein, A. S., And W. H. Greene (2012): "Usage of an estimated coefficient as a dependent variable," Economics Letters, 116(3), 316-318.

Howe, J. S., AND J. D. Shilling (1990): "REIT Advisor Performance," AREUEA Journal, 18(4), 479-500.

Jegadeesh, N., And S. Titman (1993): "Returns to Buying Winners and Selling Losers: Implications for Stock Market Efficiency," Journal of Finance, 48(1), 65-91.

KeIM, D. B. (1983): "Size-related anomalies and stock return seasonality : Further empirical evidence," Journal of Financial Economics, 12(1), 13-32.

KimeldoRF, G., AND A. R. SAmpson (1975): "Uniform representation of bivariate distributions," Communications in Statistics: Theory and Methods, 4(7), 617-627.

Kiyotaki, N., And J. Moore (1997): "Credit Cycles," Journal of Political Economy, $105(2), 211-48$.

Knight, J., C. Lizieri, And S. SAtchell (2005): "Diversification when it hurts? The joint distributions of real estate and equity markets," Journal of Property Research, 22(4), 309-323.

Koenker, R. (2005): Quantile regression. Cambridge University Press, Cambridge.

Koenker, R., And J. Bassett, Gilbert (1978): "Regression Quantiles," Econometrica, $46(1), 33-50$.

Ling, D. C., And A. NARAnjo (2015): "Returns and Information Transmission Dynamics in Public and Private Real Estate Markets," Real Estate Economics, 43(1), 163-208. 
Liow, K. H. (2012): "Co-movements and Correlations Across Asian Securitized Real Estate and Stock Markets," Real Estate Economics, 40(1), 97-129.

Liow, K. H., K. H. D. Ho, M. F. Ibrahim, And Z. Chen (2009): "Correlation and volatility dynamics in international real estate securities markets," Journal of Real Estate Finance and Economics, 39(2), 202-223.

Liow, K. H., X. Zhou, And Q. Ye (2015): "Correlation Dynamics and Determinants in International Securitized Real Estate Markets," Real Estate Economics, Forthcoming.

LiU, W. (2006): "A liquidity-augmented capital asset pricing model," Journal of Financial Economics, 82(3), 631-671.

Longin, F., AND B. Solnik (1995): "Is the correlation in international equity returns constant: 1960-1990?," Journal of International Money and Finance, 14(1), 3-26.

Longin, F., AND B. Solnik (2001): "Extreme correlation of international equity markets," Journal of Finance, 56(2), 649-676.

Markowitz, H. M. (1959): Portfolio selection: Efficient diversification of investments. J. Wiley, New York, London.

Michayluk, D., P. J. Wilson, And R. ZurbruegG (2006): "Asymmetric volatility, correlation and returns dynamics between the US and UK securitized real estate markets," Real Estate Economics, 34(1), 109-131.

Modigliani, F., AND M. Miller (1958): "The cost of capital, corporate finance and the theory of investment," American Economic Review, 48(2), 261-297.

- (1963): "Corporate income taxes and the cost of capital: a correction," American Economic Review, 53(3), 433-443.

Mosteller, F. (1977): Data analysis and regression: A second course in statistics. Addison-Wesley, Reading, Mass.; London.

Patton, A. J. (2004): "On the Out-of-Sample Importance of Skewness and Asymmetric Dependence for Asset Allocation," Journal of Financial Econometrics, 2(1), 130-168.

- (2006): "Modelling asymmetric exchange rate dependence," International Economic Review, 47(2), 527-556.

- (2009): "Copula-based methods for financial time series," in Andersen, Davis, Kreiß, Mikosch (eds.), Handbook of financial time series, Springer, New York.

Pavlov, A., E. Steiner, And S. Wachter (2015): "Macroeconomic Risk Factors and the Role of Mispriced Credit in the Returns from International Real Estate Securities," Real Estate Economics, 43(1), 241-270.

Perez-Quiros, G., And A. Timmermann (2000): "Firm Size and Cyclical Variations in Stock Returns," Journal of Finance, 55(3), 1229-1262.

Roll, R. (1988): "R2," Journal of Finance, 43(3), 541-566.

RosenberG, B., K. Reid, And R. Lanstein (1985): "Persuasive evidence of market inefficiency," Journal of Portfolio Management, 11(3), 9-17.

Simon, S., AND W. L. NG (2009): "The effect of the real estate downturn on the link between REITs and the stock market," Journal of Real Estate Portfolio Management, 15(3), 211-219.

Skiadas, C. (1997a): "Conditioning and Aggregation of Preferences," Econometrica, $65(2), 347-367$.

- (1997b): "Subjective probability under additive aggregation of conditional preferences," Journal of Economic Theory, 76(2), 242-271.

Stattman, D. (1980): "Book values and stock returns," Chicago MBA: A Journal of Selected Papers, 4, 25-45.

Sun, L., S. D. Titman, And G. J. Twite (2015): "REIT and Commercial Real Estate Returns: A Postmortem of the Financial Crisis," Real Estate Economics, 43(1), 8-36.

Sun, Q., AND K. Yung (2009): "Idiosyncratic Risk and Expected Returns of Equity Real 
Estate Investment Trusts," Journal of Real Estate Portfolio Management, 15(1), 45-57. YAnG, J., Y. Zhou, And W. Leung (2012): "Asymmetric Correlation and Volatility Dynamics among Stock, Bond, and Securitized Real Estate Markets," Journal of Real Estate Finance and Economics, 45(2), 491-521.

Zellner, A. (1962): "An Efficient Method of Estimating Seemingly Unrelated Regressions and Tests for Aggregation Bias," Journal of the American Statistical Association, 57(298), 348-368.

(1963): "Estimators for Seemingly Unrelated Regression Equations: Some Exact Finite Sample Results," Journal of the American Statistical Association, 58(304), 977992.

Zellner, A., And D. S. Huang (1962): "Further Properties of Efficient Estimators for Seemingly Unrelated Regression Equations," International Economic Review, 3(3), 300-313.

Zhou, J., And Y. GaO (2012): "Tail Dependence in International Real Estate Securities Markets," Journal of Real Estate Finance and Economics, 45(1), 128-151. 


\section{Figures and tables}

Scatter plots for simulated returns on a broad stock market index $\left(X_{1}\right)$ and a security $\left(X_{2}\right)$
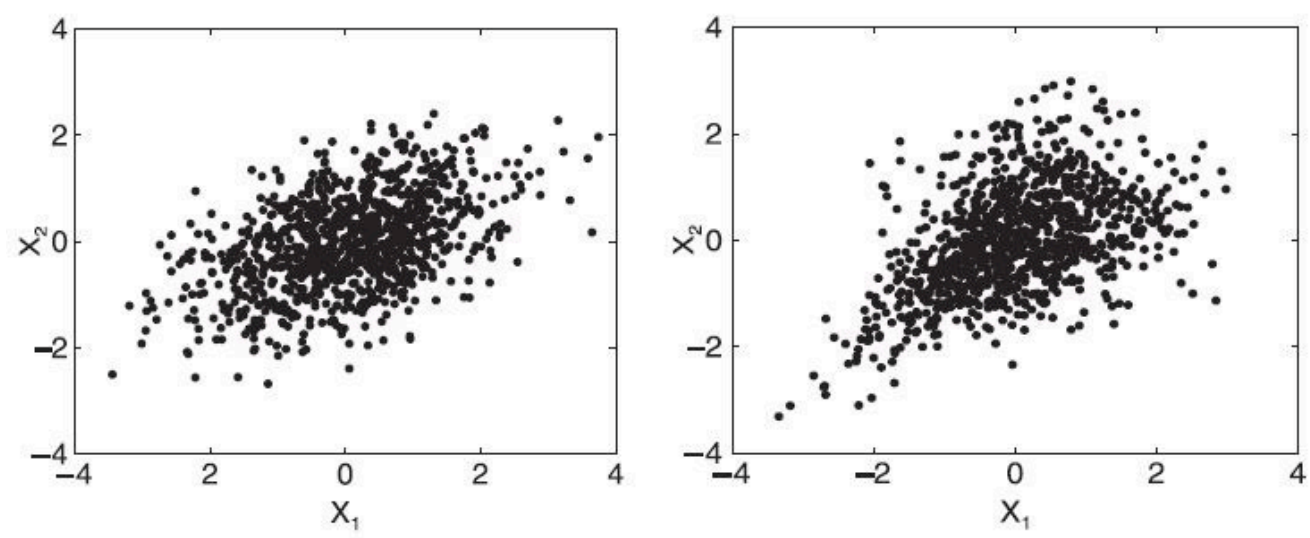

Fig. 1. The figure shows scatter plots of simulated data on the market $\left(X_{1}\right)$ and a security $\left(X_{2}\right)$ under two different assumptions about dependence patterns between the return series. The panel on the left shows an evenly spread, symmetrical distribution of returns whose dependence structure is fully captured by the familiar CAPM beta that measures the slope of a straight line through the scatter plot. The panel on the right shows an asymmetric distribution of returns with a disproportionate clustering of poor returns that leaves the slope of a straight line through the scatter plot largely unaffected.

Evolution of the number of sample firms

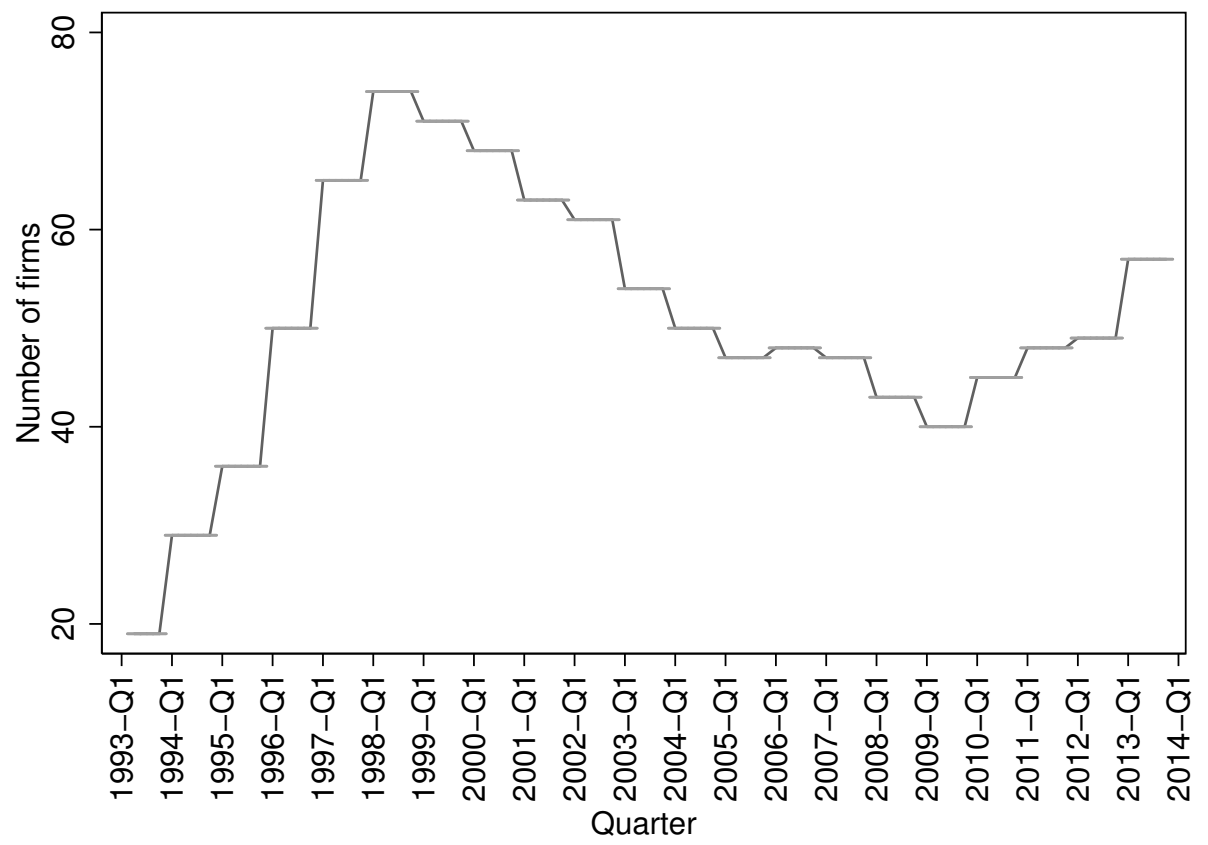

Fig. 2. The figure shows the evolution of the quarterly number of firms with complete observations in our sample over the study period 1993-2013. 


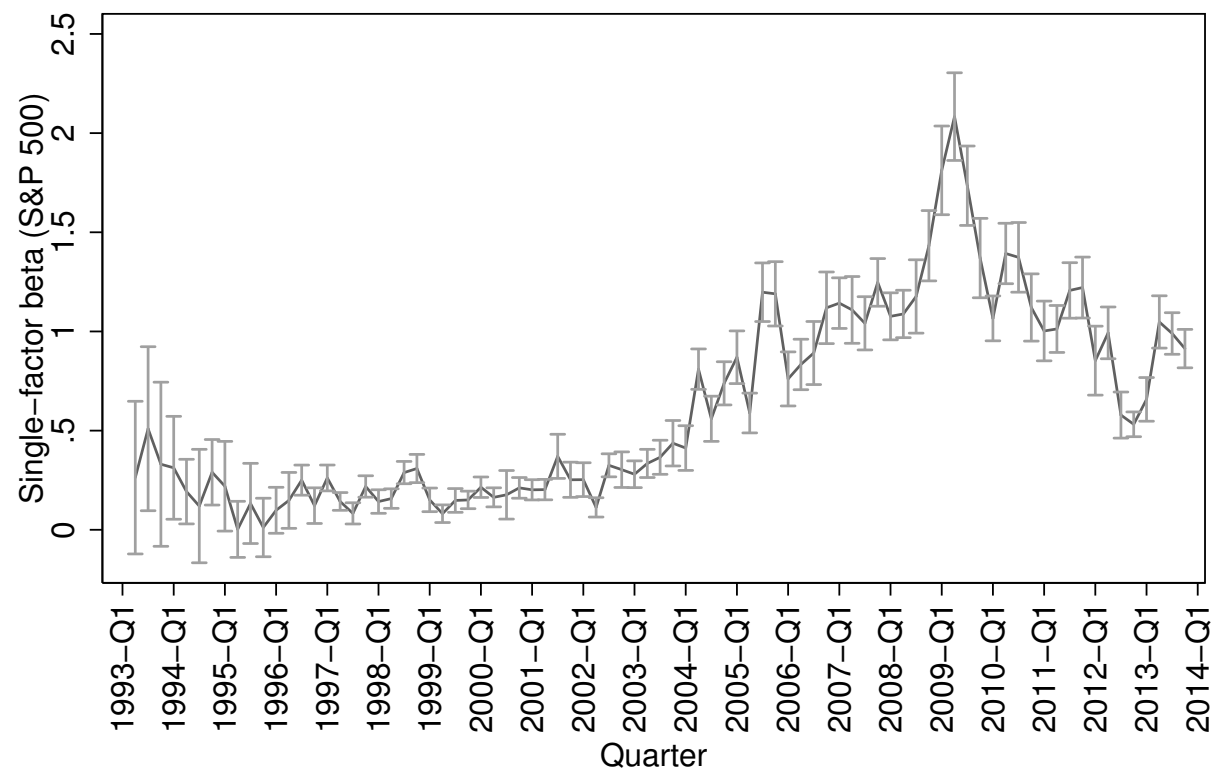

\section{$\longrightarrow$ Single-factor beta (S\&P 500) $\longmapsto 95 \%$ confidence interval}

(a) Mean single-factor beta estimate

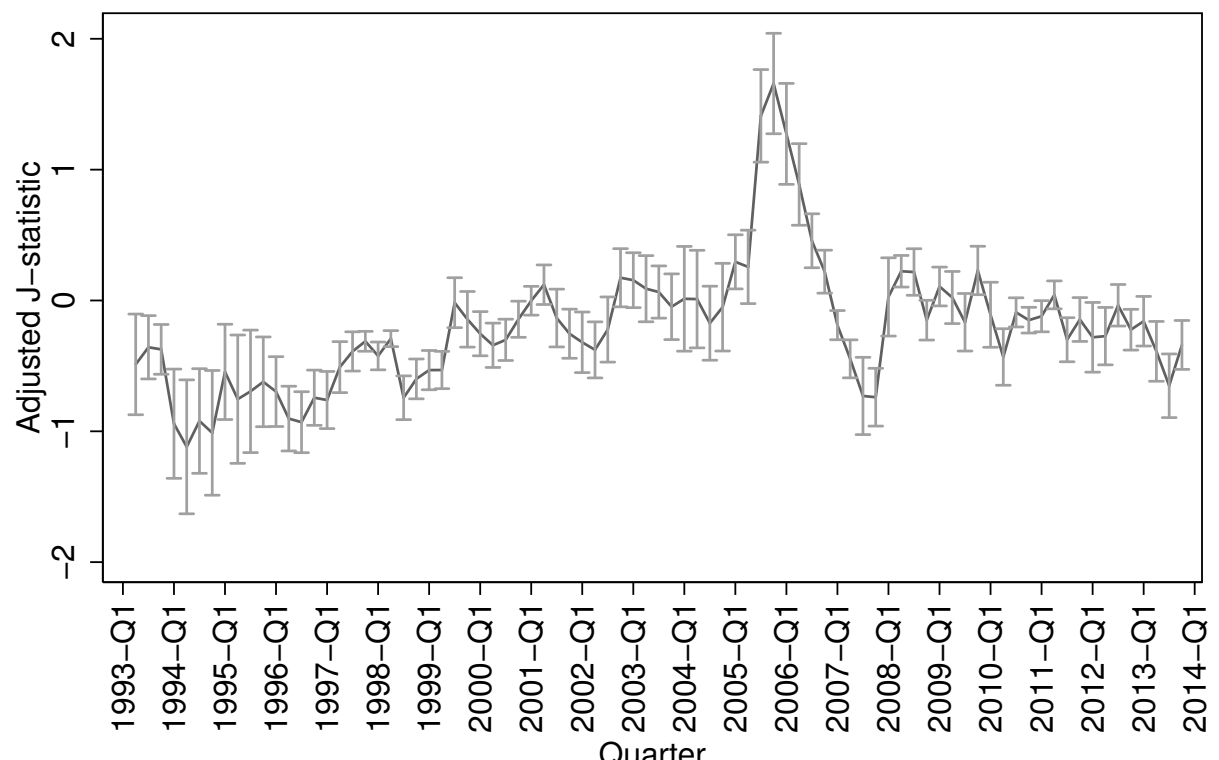
Quarter

\section{$\longrightarrow$ Adjusted J-statistic $\longmapsto 95 \%$ confidence interval}

(b) Mean Adjusted J statistic

Fig. 3. The figure shows the evolution of quarterly mean firm-level single-factor beta estimates with respect to the S\&P500 (Panel (a)) and the Adjusted J statistic (Panel (b)) over the period 1993 to 2013. Single-factor betas are obtained from quarterly firm-by-firm regressions of daily total returns on the S\&P500 index. Quarterly Adjusted J statistics are obtained from daily data on the respective REITs and the S\&P500 index. The bars indicate a $95 \%$ confidence interval around the mean estimate. 
Evolution of mean firm-quarter dependence measures relative to NBER recession dates

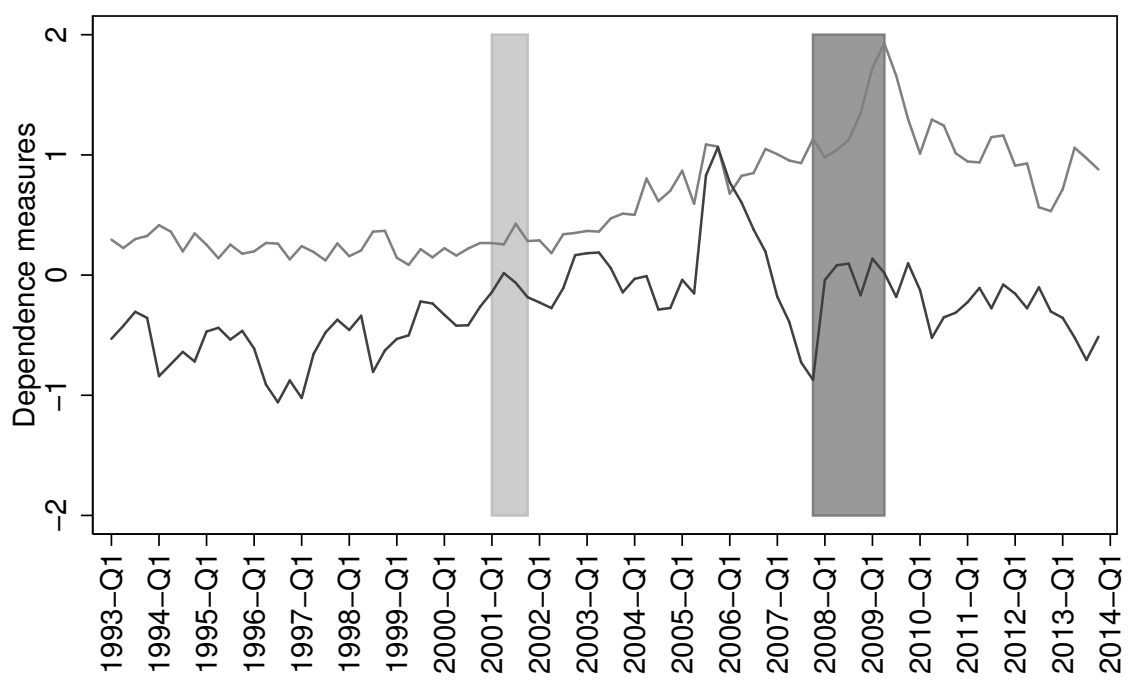

$\begin{array}{ll}\text { NBER recession } 2001 & \text { NBER recession 2007-2009 } \\ \text { Mean CAPM beta } & \text { Mean Adjusted J-statistic }\end{array}$

Fig. 4. The figure shows the evolution of quarterly mean firm-level single-factor beta estimates with respect to the S\&P500 and the Adjusted J statistic over the period 1993 to 2013. Single-factor betas are obtained from quarterly firm-by-firm regressions of daily total returns on the S\&P500 index. Quarterly Adjusted J statistics are obtained from daily data on the respective REITs and the S\&P500 index. The grey shaded areas indicate NBER recession dates. 


\section{Descriptive statistics}

\begin{tabular}{lrrrrrrrrr}
\hline Variable & Mean & SD & P5 & P25 & Median & P75 & P95 & Unit root \\
\hline Single-factor beta & 0.589 & 0.614 & -0.183 & 0.157 & 0.423 & 1.001 & 1.696 & $-48.494^{* * *}$ \\
Adjusted J statistic & -0.184 & 0.886 & -1.715 & -0.413 & -0.049 & 0.045 & 1.010 & $-30.698^{* * *}$ \\
Market leverage & 0.440 & 0.184 & 0.045 & 0.335 & 0.435 & 0.555 & 0.750 & $-11.153^{* * *}$ \\
Market-to-book ratio & 1.204 & 0.336 & 0.758 & 1.004 & 1.151 & 1.337 & 1.860 & $-5.739 * * *$ \\
Log of firm size & 12.844 & 1.835 & 9.071 & 11.904 & 13.165 & 14.186 & 15.261 & 3.697 \\
6-month return & 0.071 & 0.218 & -0.269 & -0.038 & 0.065 & 0.171 & 0.429 & $-46.578^{* * *}$ \\
36-month return & 0.488 & 0.716 & -0.558 & 0.039 & 0.449 & 0.824 & 1.721 & $-7.714^{* * *}$ \\
Turnover ratio & 0.295 & 0.297 & 0.021 & 0.102 & 0.206 & 0.382 & 0.851 & $-33.927^{* * *}$ \\
RE investment growth & 0.185 & 0.518 & -0.160 & -0.024 & 0.035 & 0.187 & 1.045 & $-72.262^{* * *}$ \\
Return on average equity & 0.072 & 0.151 & -0.090 & 0.031 & 0.071 & 0.109 & 0.241 & $-61.393^{* * *}$ \\
Federal funds rate (\%) & 3.167 & 2.252 & 0.090 & 1.000 & 3.460 & 5.280 & 6.020 & 26.459 \\
NBER recession periods & 0.105 & 0.306 & 0.000 & 0.000 & 0.000 & 0.000 & 1.000 & $-44.872^{* * *}$ \\
\hline \hline
\end{tabular}

Table 1

The table presents the descriptive statistics on the sample firms. Single-factor betas are obtained from quarterly firm-by-firm regressions of daily total returns on the S\&P500 index. Quarterly Adjusted J statistics are obtained from daily data on the respective REITs and the S\&P500 index. Market leverage is measured as Total Debt divided by the Market Value of Assets (Total Assets minus Book Equity + Market value of Equity). Firm size is the natural logarithm of the Market Capitalisation. Market-to-book ratio is the Market Value of Assets divided by the book value of Total Assets. 6-month return is the 6-month cumulative total return. 36-month return is the 36-month cumulative total return. Turnover ratio is quarterly Trading volume divided by Common Shares Outstanding. Real estate (RE) investment growth measures the rate of investment. Return on average equity measures profitability. All firm-level data and return data on the firms, the S\&P500 and the Russell 2000 is obtained form SNL Financial. Data on the federal funds rate is obtained from the Federal Reserve Bank of St Louis's Economic Database and business cycle indicators are from NBER. The study period is 1993 to 2013. The total number of observations in the final sample is 3,828 . The final column shows the inverse normal z-statistic from a Fisher-type (Augmented Dickey-Fuller) test for unit roots in unbalanced panel data proposed in Choi (2001). The null hypothesis is that no panel (firm) has a unit root in the variable concerned. We reject the null hypothesis for all but one of the firm characteristics we are interested in (firm size). Significance is indicated as follows: ${ }^{* * *} \mathrm{p}<0.01, * * \mathrm{p}<0.05, * \mathrm{p}<0.1$. 


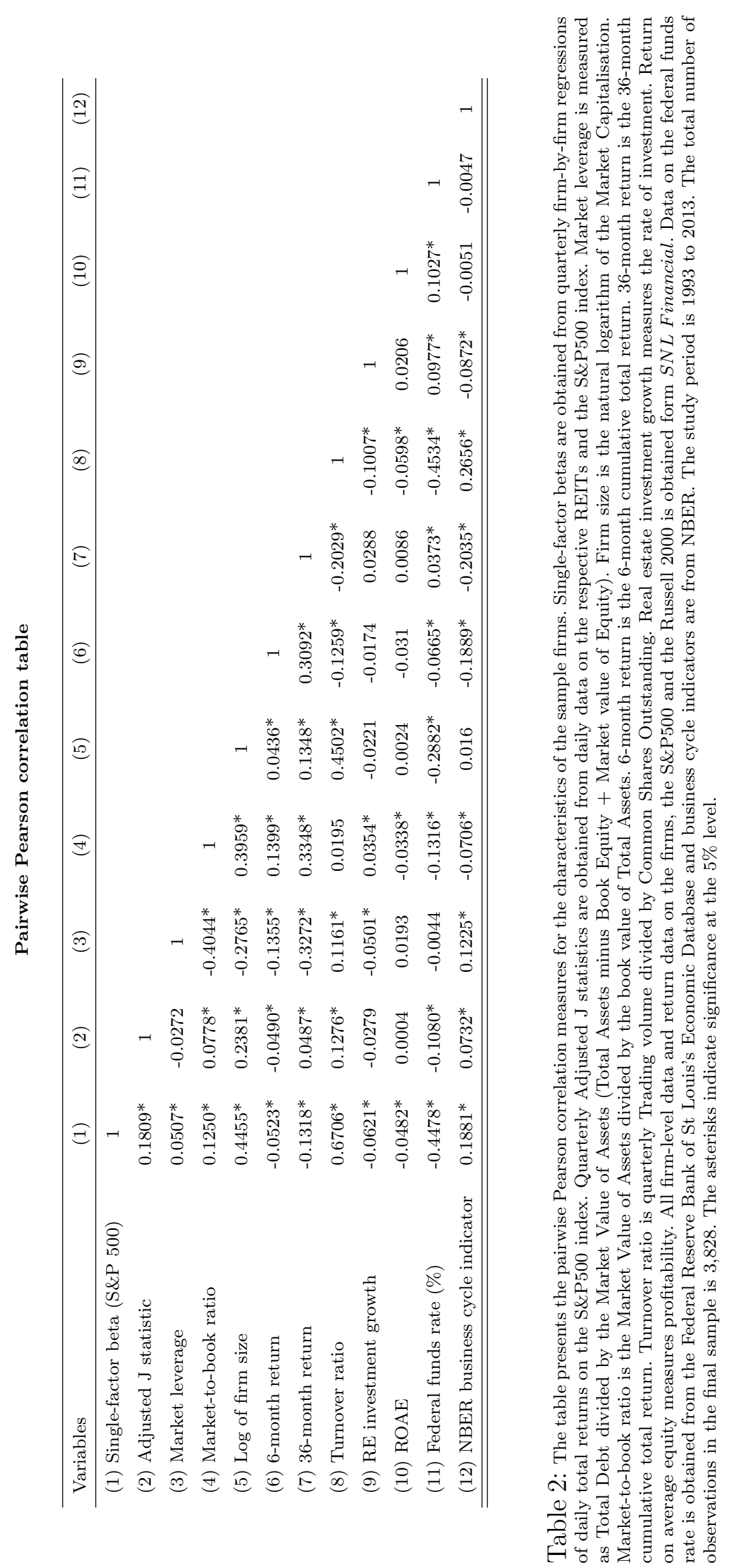


Unconditional quintile analysis for covariates of dependence measures

\begin{tabular}{lccccccc}
\hline Panel (a): CAPM Beta & 1 & 2 & 3 & 4 & 5 & Difference & (t-statistic) \\
\hline Market leverage & 0.462 & 0.417 & 0.422 & 0.421 & 0.477 & 0.015 & $(1.43)$ \\
Log of firm size & 11.647 & 12.982 & 13.322 & 13.393 & 12.895 & $1.248^{* * *}$ & $(13.14)$ \\
Market to book ratio & 1.186 & 1.219 & 1.245 & 1.226 & 1.145 & $-0.0413^{*}$ & $(-2.24)$ \\
6-month return & 0.077 & 0.074 & 0.073 & 0.062 & 0.071 & -0.005 & $(-0.40)$ \\
36-month return & 0.482 & 0.492 & 0.521 & 0.526 & 0.419 & -0.0624 & $(-1.52)$ \\
Turnover ratio & 0.198 & 0.289 & 0.312 & 0.333 & 0.342 & $0.144^{* * *}$ & $(9.37)$ \\
RE investment growth & 0.209 & 0.171 & 0.176 & 0.171 & 0.196 & -0.012 & $(-0.43)$ \\
ROAE & 0.064 & 0.071 & 0.081 & 0.076 & 0.070 & 0.006 & $(0.78)$ \\
\hline & & & & & & & \\
\hline Panel (b): Adjusted J statistic & 1 & 2 & 3 & 4 & 5 & Difference & $($ t-statistic) \\
\hline Market leverage & 0.470 & 0.437 & 0.436 & 0.430 & 0.425 & $-0.045^{* * *}$ & $(-4.60)$ \\
Log of firm size & 12.408 & 12.879 & 13.008 & 12.971 & 12.960 & $0.552^{* * *}$ & $(5.78)$ \\
Market to book ratio & 1.178 & 1.201 & 1.209 & 1.222 & 1.211 & 0.033 & $(1.91)$ \\
6-month return & 0.080 & 0.069 & 0.076 & 0.069 & 0.062 & -0.018 & $(-1.55)$ \\
36-month return & 0.439 & 0.471 & 0.525 & 0.510 & 0.495 & 0.056 & $(1.50)$ \\
Turnover ratio & 0.266 & 0.297 & 0.315 & 0.296 & 0.301 & $0.0349^{*}$ & $(2.38)$ \\
RE investment growth & 0.191 & 0.176 & 0.194 & 0.173 & 0.189 & -0.003 & $(-0.10)$ \\
ROAE & 0.072 & 0.074 & 0.074 & 0.070 & 0.072 & -0.001 & $(-0.10)$ \\
\hline \hline
\end{tabular}

Table 3

The table presents the results from the unconditional quintile analysis of the covariates of the dependence measures. Quintiles are formed by sorting firms into quarterly groups according to the value of their respective dependence measures. In Panel (a), single-factor betas are obtained from quarterly firm-by-firm regressions of daily total returns on the S\&P500 index. In Panel (b), quarterly Adjusted J statistics are obtained from daily data on the respective REITs and the S\&P500 index. Market leverage is measured as Total Debt divided by the Market Value of Assets (Total Assets minus Book Equity + Market value of Equity). Firm size is the natural logarithm of the Market Capitalisation. Market-to-book ratio is the Market Value of Assets divided by the book value of Total Assets. 6month return is the 6-month cumulative total return. 36-month return is the 36-month cumulative total return. Turnover ratio is quarterly Trading volume divided by Common Shares Outstanding. Real estate investment growth measures the rate of investment. Return on average equity measures profitability. L.Beta is the first lag of the singlefactor beta. All firm-level data and return data on the firms and the S\&P500 is obtained form SNL Financial. Data on the federal funds rate is obtained from the Federal Reserve Bank of St Louis's Economic Database and business cycle indicators are from NBER. Difference indicates the difference in the mean characteristic values across the $1^{\text {st }}$ and $5^{t h}$ quintiles of the dependence measures. The corresponding t-statistics are shown in parentheses. Significance is indicated as follows: ${ }^{* * *} \mathrm{p}<0.01,{ }^{* *} \mathrm{p}<0.05,{ }^{*} \mathrm{p}<0.1$. 


\section{Regression results for single-factor beta with respect to S\&P 500 index}

\begin{tabular}{|c|c|c|c|}
\hline & (1) & $(2)$ & (3) \\
\hline VARIABLES & Full period & Recession & Non-recession \\
\hline \multirow[t]{2}{*}{ Market leverage } & 0.043 & 0.174 & 0.046 \\
\hline & $(0.04)$ & $(0.12)$ & $(0.04)$ \\
\hline \multirow[t]{2}{*}{ Log of firm size } & $0.043^{* * *}$ & $0.059^{* * *}$ & $0.043^{* * *}$ \\
\hline & 0.00 & $(0.01)$ & 0.00 \\
\hline \multirow[t]{2}{*}{ Market to book ratio } & $-0.066^{* * *}$ & $-0.168^{* *}$ & $-0.061^{* * *}$ \\
\hline & $(0.02)$ & $(0.07)$ & $(0.02)$ \\
\hline \multirow[t]{2}{*}{6 -month return } & $0.063^{*}$ & 0.122 & $0.069^{*}$ \\
\hline & $(0.03)$ & $(0.08)$ & $(0.04)$ \\
\hline \multirow[t]{2}{*}{ 36-month return } & $-0.024^{* *}$ & -0.013 & $-0.025^{* *}$ \\
\hline & $(0.01)$ & $(0.04)$ & $(0.01)$ \\
\hline \multirow[t]{2}{*}{ Turnover ratio } & $0.345^{* * *}$ & $0.378^{* * *}$ & $0.270^{* * *}$ \\
\hline & $(0.03)$ & $(0.06)$ & $(0.04)$ \\
\hline \multirow[t]{2}{*}{$\mathrm{RE}$ investment growth } & 0.009 & -0.061 & 0.01 \\
\hline & $(0.01)$ & $(0.04)$ & $(0.01)$ \\
\hline \multirow[t]{2}{*}{ ROAE } & -0.005 & 0.075 & -0.029 \\
\hline & $(0.04)$ & $(0.08)$ & $(0.04)$ \\
\hline \multirow[t]{2}{*}{ Federal funds rate $(\%)$} & $-0.094^{* * *}$ & $-0.125^{* * *}$ & $-0.113^{* * *}$ \\
\hline & $(0.02)$ & $(0.02)$ & $(0.02)$ \\
\hline \multirow[t]{2}{*}{ NBER business cycle indicator } & $0.231^{* * *}$ & $\mathrm{n} / \mathrm{a}$ & $\mathrm{n} / \mathrm{a}$ \\
\hline & $(0.08)$ & $\mathrm{n} / \mathrm{a}$ & $\mathrm{n} / \mathrm{a}$ \\
\hline \multirow[t]{2}{*}{ L.beta } & $0.350^{* * *}$ & $0.513^{* * *}$ & $0.333^{* * *}$ \\
\hline & $(0.02)$ & $(0.05)$ & $(0.02)$ \\
\hline \multirow[t]{2}{*}{ Constant } & 0.138 & 0.068 & $0.223^{* *}$ \\
\hline & $(0.10)$ & $(0.25)$ & $(0.11)$ \\
\hline Observations & 3,828 & 401 & 3,427 \\
\hline R-squared & 0.709 & 0.870 & 0.665 \\
\hline Sector effects & Yes & Yes & Yes \\
\hline Quarter effects & Yes & Yes & Yes \\
\hline
\end{tabular}

Table 4

The table presents the regression results for the firm-quarter observations of the single-factor beta with respect to the S\&P500. The single-factor beta is obtained from quarterly firm-by-firm regressions of daily total returns on the S\&P500 index. The lag of beta is included as a control variable. Market leverage is measured as Total Debt divided by the Market Value of Assets (Total Assets minus Book Equity + Market value of Equity). Firm size is the natural logarithm of the Market Capitalisation. Market-to-book ratio is the Market Value of Assets divided by the book value of Total Assets. 6-month return is the 6-month cumulative total return. 36-month return is the 36month cumulative total return. Turnover ratio is quarterly Trading volume divided by Common Shares Outstanding. Real estate investment growth measures the rate of investment. Return on average equity measures profitability. L.Beta is the first lag of the single-factor beta. All firm-level data and return data on the firms and the S\&P500 is obtained form SNL Financial. Data on the federal funds rate is obtained from the Federal Reserve Bank of St Louis's Economic Database and business cycle indicators are from NBER. Standard errors, shown in parentheses, are robust to the estimated dependent variable bias, using the weighting procedure proposed in Hornstein and Greene (2012). Significance is indicated as follows: $* * * \mathrm{p}<0.01,{ }^{*} * \mathrm{p}<0.05,{ }^{*} \mathrm{p}<0.1$. 
Regression results for Adjusted J statistic with respect to S\&P 500 index

\begin{tabular}{|c|c|c|c|}
\hline & (1) & $(2)$ & $(3)$ \\
\hline VARIABLES & Full period & Recession & Non-recession \\
\hline \multirow[t]{2}{*}{ Market leverage } & $-0.134^{* *}$ & $-0.590^{* * *}$ & -0.080 \\
\hline & $(0.07)$ & $(0.22)$ & $(0.07)$ \\
\hline \multirow[t]{2}{*}{ Log of firm size } & $0.027^{* * *}$ & -0.014 & $0.028^{* * *}$ \\
\hline & $(0.01)$ & $(0.03)$ & $(0.01)$ \\
\hline \multirow[t]{2}{*}{ Market to book ratio } & -0.058 & 0.110 & $-0.069^{*}$ \\
\hline & $(0.04)$ & $(0.13)$ & $(0.04)$ \\
\hline \multirow[t]{2}{*}{ 6-month return } & $-0.227^{* * *}$ & -0.054 & $-0.262^{* * *}$ \\
\hline & $(0.06)$ & $(0.15)$ & $(0.06)$ \\
\hline \multirow[t]{2}{*}{ 36-month return } & $0.037^{* *}$ & 0.052 & $0.036^{*}$ \\
\hline & $(0.02)$ & $(0.08)$ & $(0.02)$ \\
\hline \multirow[t]{2}{*}{ Turnover ratio } & -0.031 & 0.158 & -0.054 \\
\hline & $(0.06)$ & $(0.11)$ & $(0.07)$ \\
\hline \multirow[t]{2}{*}{ RE investment growth } & $0.042^{* *}$ & $0.208^{* *}$ & $0.033^{*}$ \\
\hline & $(0.02)$ & $(0.08)$ & $(0.02)$ \\
\hline \multirow[t]{2}{*}{ ROAE } & 0.002 & 0.131 & -0.042 \\
\hline & $(0.06)$ & $(0.14)$ & $(0.07)$ \\
\hline \multirow[t]{2}{*}{ Federal funds rate $(\%)$} & 0.002 & $0.067^{*}$ & 0.000 \\
\hline & $(0.03)$ & $(0.04)$ & $(0.03)$ \\
\hline \multirow[t]{2}{*}{ NBER business cycle indicator } & $0.624^{* * *}$ & $\mathrm{n} / \mathrm{a}$ & $\mathrm{n} / \mathrm{a}$ \\
\hline & $(0.13)$ & $\mathrm{n} / \mathrm{a}$ & $\mathrm{n} / \mathrm{a}$ \\
\hline \multirow[t]{2}{*}{ L.beta } & $0.046^{*}$ & 0.067 & 0.046 \\
\hline & $(0.03)$ & $(0.08)$ & $(0.03)$ \\
\hline \multirow[t]{2}{*}{ L.jstat } & $0.636^{* * *}$ & $0.545^{* * *}$ & $0.638^{* * *}$ \\
\hline & $(0.01)$ & $(0.05)$ & $(0.01)$ \\
\hline \multirow[t]{2}{*}{ Constant } & $-0.479 * * *$ & 0.175 & $-0.433^{* *}$ \\
\hline & $(0.17)$ & $(0.45)$ & $(0.19)$ \\
\hline Observations & 3,828 & 401 & 3,427 \\
\hline R-squared & 0.584 & 0.371 & 0.598 \\
\hline Sector effects & Yes & Yes & Yes \\
\hline Quarter effects & Yes & Yes & Yes \\
\hline
\end{tabular}

Table 5

The table presents the regression results for the firm-quarter observations of the Adjusted J statistic with respect to the S\&P500. The lags of the Adjusted J statistic and the single-factor beta are included as a control variable. Market leverage is measured as Total Debt divided by the Market Value of Assets (Total Assets minus Book Equity + Market value of Equity). Firm size is the natural logarithm of the Market Capitalisation. Market-to-book ratio is the Market Value of Assets divided by the book value of Total Assets. 6-month return is the 6-month cumulative total return. 36-month return is the 36-month cumulative total return. Turnover ratio is quarterly Trading volume divided by Common Shares Outstanding. Real estate investment growth measures the rate of investment. Return on average equity measures profitability. L.Beta is the first lag of the single-factor beta. All firm-level data and return data on the firms and the S\&P500 is obtained form SNL Financial. Data on the federal funds rate is obtained from the Federal Reserve Bank of St Louis's Economic Database and business cycle indicators are from NBER. Standard errors, shown in parentheses, are robust to the estimated dependent variable bias, using the weighting procedure proposed in Hornstein and Greene (2012). Significance is indicated as follows: *** $\mathrm{p}<0.01, * * \mathrm{p}<0.05, * \mathrm{p}<0.1$. 
Comparison of regression coefficients for market leverage across models with varying degrees of winsorising the sample data

\begin{tabular}{lcccccc}
\hline Effect of leverage & \multicolumn{3}{c}{ CAPM beta } & \multicolumn{3}{c}{ Adjusted J statistic } \\
Model & Full period & Recession & Non-recession & Full period & Recession & Non-recession \\
\hline Baseline & 0.043 & 0.174 & 0.046 & -0.134 & -0.590 & -0.080 \\
Test (i) & 0.051 & 0.210 & 0.051 & -0.149 & -0.599 & -0.084 \\
Test (ii) & 0.055 & 0.233 & 0.052 & -0.163 & -0.600 & -0.096 \\
\hline \hline
\end{tabular}

Table 6

The table summarises the regression coefficients on market leverage from the models in Tables 4 and 5 . Test (i) shows the coefficients obtained when only firm characteristic variables are winsorised. Test (ii) shows the coefficients obtained when no variables are winsorised. Significance levels remain unchanged from the main results in Tables 4 and 5 . 


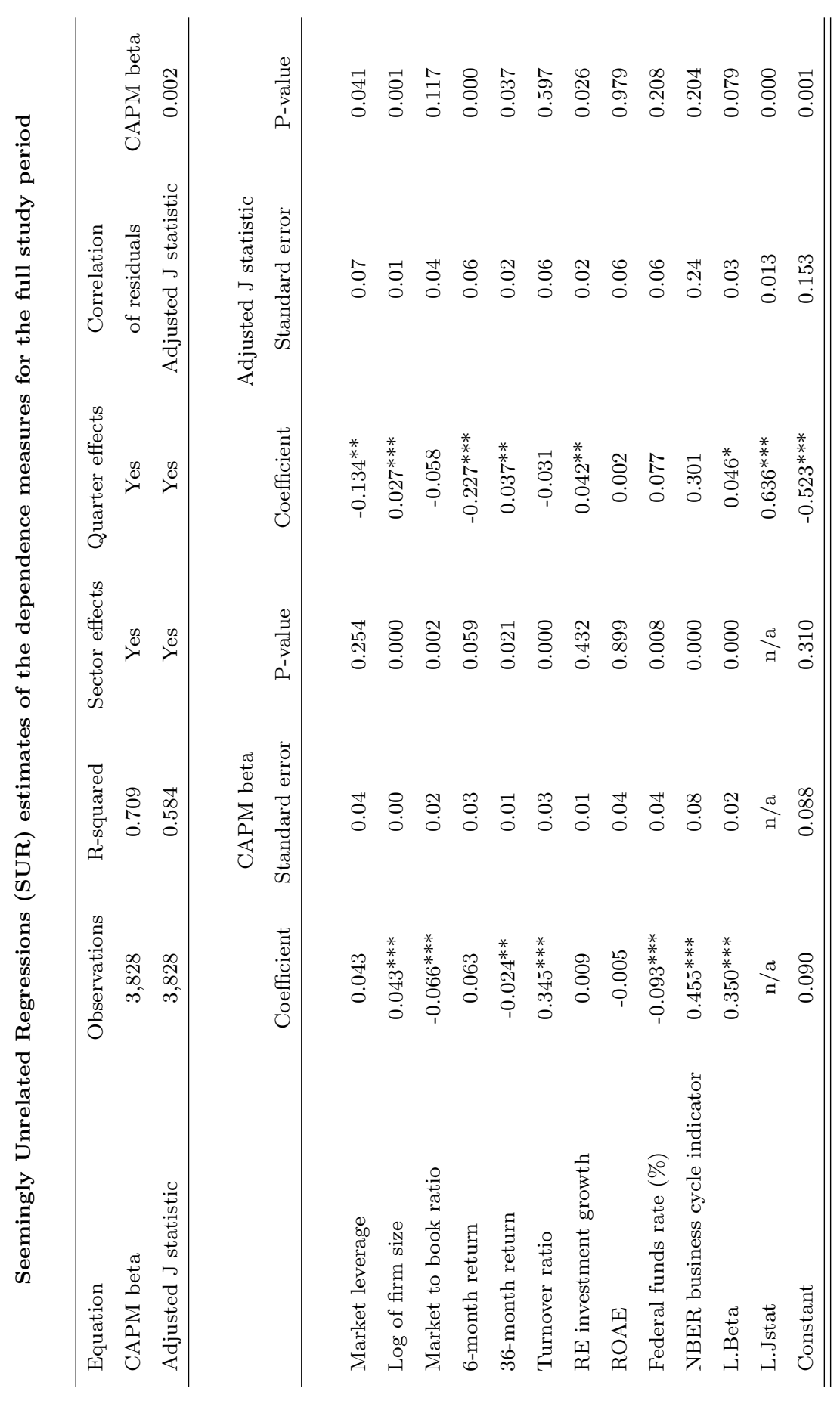

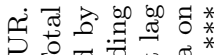

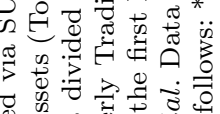

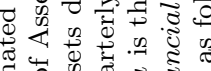

政政

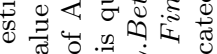

8

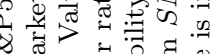

$0 \sum_{0}^{0}$

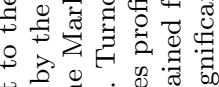

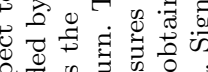

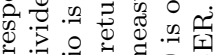

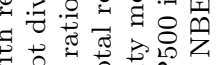

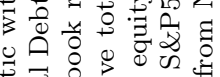

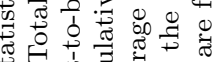

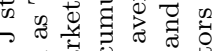

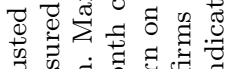

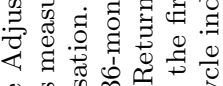

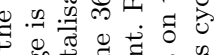

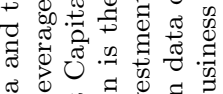

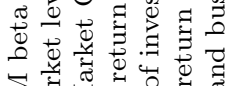

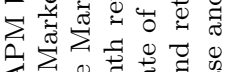
U. ఫ प्ष

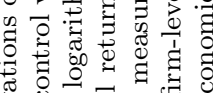

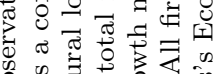

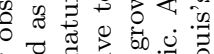

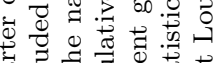

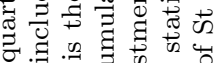
i o

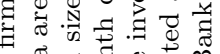

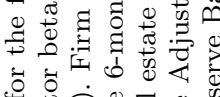

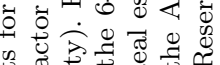

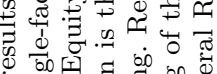

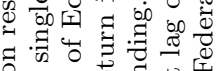

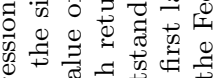

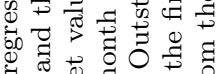
4.0

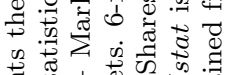

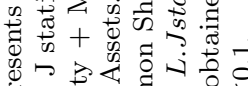

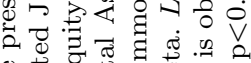

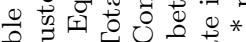

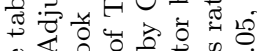

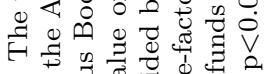

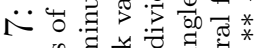
0.

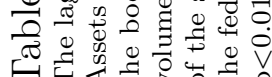


Regression results for Alpha with respect to S\&P 500 index

\begin{tabular}{|c|c|c|c|}
\hline & (1) & $(2)$ & (3) \\
\hline VARIABLES & Full period & Recession & Non-recession \\
\hline \multirow[t]{2}{*}{ Market leverage } & 0.018 & -0.039 & 0.033 \\
\hline & $(0.03)$ & $(0.13)$ & $(0.02)$ \\
\hline \multirow[t]{2}{*}{ Log of firm size } & $-0.017 * * *$ & 0.01 & $-0.020^{* * *}$ \\
\hline & 0.00 & $(0.01)$ & 0.00 \\
\hline \multirow[t]{2}{*}{ Market to book ratio } & $-0.027^{*}$ & -0.036 & -0.022 \\
\hline & $(0.01)$ & $(0.08)$ & $(0.01)$ \\
\hline \multirow[t]{2}{*}{ 6-month return } & $-0.070^{* * *}$ & $0.217^{* *}$ & $-0.119^{* * *}$ \\
\hline & $(0.03)$ & $(0.10)$ & $(0.03)$ \\
\hline \multirow[t]{2}{*}{ 36-month return } & $0.022^{* * *}$ & -0.025 & $0.026^{* * *}$ \\
\hline & $(0.01)$ & $(0.05)$ & $(0.01)$ \\
\hline \multirow[t]{2}{*}{ Turnover ratio } & -0.03 & -0.056 & -0.012 \\
\hline & $(0.02)$ & $(0.06)$ & $(0.03)$ \\
\hline \multirow[t]{2}{*}{$\mathrm{RE}$ investment growth } & $-0.015^{* *}$ & -0.017 & $-0.016^{* *}$ \\
\hline & $(0.01)$ & $(0.05)$ & $(0.01)$ \\
\hline \multirow[t]{2}{*}{ ROAE } & 0.031 & 0.061 & 0.021 \\
\hline & $(0.02)$ & $(0.08)$ & $(0.03)$ \\
\hline \multirow[t]{2}{*}{ Federal funds rate $(\%)$} & 0.005 & -0.006 & 0.000 \\
\hline & $(0.01)$ & $(0.02)$ & $(0.01)$ \\
\hline \multirow[t]{2}{*}{ NBER business cycle indicator } & -0.042 & $\mathrm{n} / \mathrm{a}$ & $\mathrm{n} / \mathrm{a}$ \\
\hline & $(0.06)$ & $\mathrm{n} / \mathrm{a}$ & $\mathrm{n} / \mathrm{a}$ \\
\hline \multirow[t]{2}{*}{ L.alpha } & $4.094^{* *}$ & 5.889 & 2.661 \\
\hline & $(1.86)$ & $(5.62)$ & $(1.99)$ \\
\hline \multirow[t]{2}{*}{ Constant } & $0.309^{* * *}$ & 0.115 & $0.389^{* * *}$ \\
\hline & -0.06 & -0.27 & -0.07 \\
\hline Observations & 3,828 & 401 & 3,427 \\
\hline R-squared & 0.191 & 0.13 & 0.221 \\
\hline Sector effects & Yes & Yes & Yes \\
\hline Quarter effects & Yes & Yes & Yes \\
\hline
\end{tabular}

Table 8

The table presents the regression results for the firm-quarter observations of the alpha coefficient obtained from the CAPM regressions with respect to the S\&P500. The lag of the alpha estimate is included as a control variable. Market leverage is measured as Total Debt divided by the Market Value of Assets (Total Assets minus Book Equity + Market value of Equity). Firm size is the natural logarithm of the Market Capitalisation. Market-to-book ratio is the Market Value of Assets divided by the book value of Total Assets. 6-month return is the 6-month cumulative total return. 36-month return is the 36-month cumulative total return. Turnover ratio is quarterly Trading volume divided by Common Shares Outstanding. Real estate investment growth measures the rate of investment. Return on average equity measures profitability. L.Beta is the first lag of the single-factor beta. All firm-level data and return data on the firms and the S\&P500 is obtained form SNL Financial. Data on the federal funds rate is obtained from the Federal Reserve Bank of St Louis's Economic Database and business cycle indicators are from NBER. Standard errors, shown in parentheses, are robust to the estimated dependent variable bias, using the weighting procedure proposed in Hornstein and Greene (2012). Significance is indicated as follows: *** $\mathrm{p}<0.01,{ }^{* *} \mathrm{p}<0.05,{ }^{*} \mathrm{p}<0.1$. 
Quantile regression results for CAPM beta and Adjusted J statistic with respect to S\&P 500 index, full study period 1993-2013

\begin{tabular}{|c|c|c|}
\hline & (1) & $(2)$ \\
\hline VARIABLES & Beta & Adjusted J statistic \\
\hline \multirow{2}{*}{ Market leverage } & $0.037^{*}$ & $-0.073^{* *}$ \\
\hline & $(0.02)$ & $(0.03)$ \\
\hline \multirow[t]{2}{*}{ Log of firm size } & $0.035^{* * *}$ & 0.000 \\
\hline & 0.00 & 0.00 \\
\hline \multirow[t]{2}{*}{ Market to book ratio } & $-0.060^{* * *}$ & 0.009 \\
\hline & $(0.01)$ & $(0.01)$ \\
\hline \multirow[t]{2}{*}{ 6-month return } & $0.106^{* * *}$ & -0.033 \\
\hline & $(0.02)$ & $(0.03)$ \\
\hline \multirow[t]{2}{*}{ 36-month return } & -0.004 & 0.014 \\
\hline & $(0.01)$ & $(0.01)$ \\
\hline \multirow[t]{2}{*}{ Turnover ratio } & $0.191^{* * *}$ & 0.015 \\
\hline & $(0.02)$ & $(0.02)$ \\
\hline \multirow[t]{2}{*}{$\mathrm{RE}$ investment growth } & -0.005 & 0.01 \\
\hline & $(0.01)$ & $(0.01)$ \\
\hline \multirow[t]{2}{*}{ ROAE } & 0.017 & 0.001 \\
\hline & $(0.02)$ & $(0.02)$ \\
\hline \multirow[t]{2}{*}{ Federal funds rate $(\%)$} & $-0.076^{* * *}$ & -0.035 \\
\hline & $(0.01)$ & $(0.03)$ \\
\hline \multirow[t]{2}{*}{ NBER business cycle indicator } & $0.828^{* * *}$ & -0.064 \\
\hline & $(0.04)$ & $(0.07)$ \\
\hline \multirow[t]{2}{*}{ L.beta } & $0.415^{* * *}$ & 0.016 \\
\hline & $(0.01)$ & $(0.01)$ \\
\hline \multirow[t]{2}{*}{ L.jstat } & $\mathrm{n} / \mathrm{a}$ & $0.596^{* * *}$ \\
\hline & $\mathrm{n} / \mathrm{a}$ & $(0.01)$ \\
\hline \multirow[t]{2}{*}{ Constant } & -0.026 & 0.021 \\
\hline & $(0.05)$ & $(0.09)$ \\
\hline Observations & 3,828 & 3,828 \\
\hline Sector effects & Yes & Yes \\
\hline Quarter effects & Yes & Yes \\
\hline
\end{tabular}

Table 9

The table presents the regression results for the firm-quarter observations of the CAPM beta and Adjusted J statistic with respect to the S\&P500 over the full study period using quantile (median) regression. The lags of the CAPM beta and Adjusted J statistic estimates are included as a control variable. Market leverage is measured as Total Debt divided by the Market Value of Assets (Total Assets minus Book Equity + Market value of Equity). Firm size is the natural logarithm of the Market Capitalisation. Market-to-book ratio is the Market Value of Assets divided by the book value of Total Assets. 6-month return is the 6-month cumulative total return. 36-month return is the 36-month cumulative total return. Turnover ratio is quarterly Trading volume divided by Common Shares Outstanding. Real estate investment growth measures the rate of investment. Return on average equity measures profitability. L.Beta is the first lag of the single-factor beta. All firm-level data and return data on the firms and the S\&P500 is obtained form SNL Financial. Data on the federal funds rate is obtained from the Federal Reserve Bank of St Louis's Economic Database and business cycle indicators are from NBER. Standard errors, shown in parentheses, are robust to heteroskedasticity. Significance is indicated as follows: ${ }^{* * *} \mathrm{p}<0.01,{ }^{* *} \mathrm{p}<0.05,{ }^{*} \mathrm{p}<0.1$. 
Sector fixed effects recovered from main regression analysis, full study period 1993-2013

\begin{tabular}{llcccc}
\hline & Full period & \multicolumn{2}{c}{ CAPM beta } & \multicolumn{2}{c}{ Adjusted J statistic } \\
No. & Sector & Coefficient & (Standard error) & Coefficient & (Standard error) \\
\hline 1 & Casino & Reference & $\mathrm{n} / \mathrm{a}$ & Reference & $\mathrm{n} / \mathrm{a}$ \\
2 & Diversified & -0.048 & $(0.04)$ & -0.030 & $(0.06)$ \\
3 & Health Care & -0.029 & $(0.04)$ & 0.049 & $(0.07)$ \\
4 & Hotel & 0.056 & $(0.04)$ & 0.045 & $(0.07)$ \\
5 & Industrial & 0.004 & $(0.04)$ & 0.054 & $(0.07)$ \\
6 & Multi-Family & $-0.086^{* *}$ & $(0.04)$ & 0.072 & $(0.06)$ \\
7 & Office & -0.035 & $(0.04)$ & 0.003 & $(0.06)$ \\
8 & Other Retail & 0.023 & $(0.04)$ & 0.090 & $(0.07)$ \\
9 & Regional Mall & 0.046 & $(0.04)$ & 0.087 & $(0.07)$ \\
10 & Self-Storage & -0.025 & $(0.06)$ & 0.037 & $(0.11)$ \\
11 & Shopping Center & 0.004 & $(0.04)$ & 0.059 & $(0.06)$ \\
12 & Specialty & $-0.112^{* * *}$ & $(0.04)$ & 0.038 & $(0.07)$ \\
\hline \hline
\end{tabular}

Table 10

The table presents the regression coefficients associated with the sector fixed effects that were included for robustness in the main regression results for the CAPM beta and Adjusted J statistic with respect to the S\&P500 over the full study period form Tables 4 and 5. Standard errors, shown in parentheses, are robust to the estimated dependent variable bias, using the weighting procedure proposed in Hornstein and Greene (2012). Significance is indicated as follows: *** $\mathrm{p}<0.01, * * \mathrm{p}<0.05, * \mathrm{p}<0.1$. 
Regression results for $R^{2}$ measure of synchronicity with respect to S\&P 500 index

\begin{tabular}{|c|c|c|c|}
\hline & $(1)$ & $(2)$ & $(3)$ \\
\hline VARIABLES & Full period & Recession & Non-recession \\
\hline \multirow[t]{2}{*}{ Market leverage } & $-0.034^{* * *}$ & -0.030 & $-0.030^{* * *}$ \\
\hline & $(0.01)$ & $(0.04)$ & $(0.01)$ \\
\hline \multirow[t]{2}{*}{ Log of firm size } & $0.017^{* * *}$ & $0.023^{* * *}$ & $0.017^{* * *}$ \\
\hline & 0.00 & 0.00 & 0.00 \\
\hline \multirow[t]{2}{*}{ Market to book ratio } & $-0.017^{* * *}$ & $-0.040^{*}$ & $-0.016^{* * *}$ \\
\hline & $(0.01)$ & $(0.02)$ & $(0.01)$ \\
\hline \multirow[t]{2}{*}{ 6-month return } & $0.038^{* * *}$ & $0.082^{* * *}$ & $0.030^{* * *}$ \\
\hline & $(0.01)$ & $(0.03)$ & $(0.01)$ \\
\hline \multirow[t]{2}{*}{ 36-month return } & -0.002 & 0.005 & -0.002 \\
\hline & 0.00 & $(0.01)$ & 0.00 \\
\hline \multirow[t]{2}{*}{ Turnover ratio } & $0.080^{* * *}$ & $0.115^{* * *}$ & $0.060^{* * *}$ \\
\hline & $(0.01)$ & $(0.02)$ & $(0.01)$ \\
\hline \multirow[t]{2}{*}{ RE investment growth } & -0.002 & -0.012 & -0.002 \\
\hline & 0.00 & $(0.01)$ & 0.00 \\
\hline \multirow[t]{2}{*}{ ROAE } & $0.022^{* *}$ & 0.031 & $0.021^{* *}$ \\
\hline & $(0.01)$ & $(0.02)$ & $(0.01)$ \\
\hline \multirow[t]{2}{*}{ Federal funds rate $(\%)$} & $-0.011^{* * *}$ & $-0.032^{* * *}$ & $-0.015^{* * *}$ \\
\hline & 0.00 & $(0.01)$ & 0.00 \\
\hline \multirow[t]{2}{*}{ NBER business cycle indicator } & $0.090^{* * *}$ & $\mathrm{n} / \mathrm{a}$ & $\mathrm{n} / \mathrm{a}$ \\
\hline & $(0.02)$ & $\mathrm{n} / \mathrm{a}$ & $\mathrm{n} / \mathrm{a}$ \\
\hline \multirow[t]{2}{*}{ L.R Squared } & $0.426^{* * *}$ & $0.401^{* * *}$ & $0.418^{* * *}$ \\
\hline & $(0.01)$ & $(0.05)$ & $(0.02)$ \\
\hline \multirow[t]{2}{*}{ Constant } & $-0.057^{* *}$ & -0.012 & -0.037 \\
\hline & $(0.02)$ & $(0.08)$ & $(0.02)$ \\
\hline Observations & 3,825 & 401 & 3,424 \\
\hline R-squared & 0.826 & 0.869 & 0.812 \\
\hline Sector effects & Yes & Yes & Yes \\
\hline Quarter effects & Yes & Yes & Yes \\
\hline
\end{tabular}

Table 11

The table presents the regression results for the firm-quarter observations of the $R^{2}$ measure of synchronicity obtained from the CAPM regressions with respect to the S\&P500. The lag of the $R^{2}$ estimate is included as a control variable. Market leverage is measured as Total Debt divided by the Market Value of Assets (Total Assets minus Book Equity + Market value of Equity). Firm size is the natural logarithm of the Market Capitalisation. Market-to-book ratio is the Market Value of Assets divided by the book value of Total Assets. 6-month return is the 6-month cumulative total return. 36-month return is the 36-month cumulative total return. Turnover ratio is quarterly Trading volume divided by Common Shares Outstanding. Real estate investment growth measures the rate of investment. Return on average equity measures profitability. L.Beta is the first lag of the single-factor beta. All firm-level data and return data on the firms and the S\&P500 is obtained form SNL Financial. Data on the federal funds rate is obtained from the Federal Reserve Bank of St Louis's Economic Database and business cycle indicators are from NBER. Standard errors, shown in parentheses, are robust to the estimated dependent variable bias, using the weighting procedure proposed in Hornstein and Greene (2012). Significance is indicated as follows: *** $\mathrm{p}<0.01, * * \mathrm{p}<0.05,{ }^{*} \mathrm{p}<0.1$. 
Regression results for negative and positive Adjusted $\mathbf{J}$ statistic with respect to $\mathrm{S} \& \mathrm{P} 500$ index

\begin{tabular}{|c|c|c|}
\hline & $(1)$ & $(2)$ \\
\hline VARIABLES & Negative J-stat & Positive J-stat \\
\hline \multirow[t]{2}{*}{ Market leverage } & $-0.153^{*}$ & -0.143 \\
\hline & $(0.08)$ & $(0.11)$ \\
\hline \multirow[t]{2}{*}{ Log of firm size } & $0.027^{* * *}$ & 0.008 \\
\hline & $(0.01)$ & $(0.01)$ \\
\hline \multirow[t]{2}{*}{ Market to book ratio } & -0.060 & -0.047 \\
\hline & $(0.05)$ & $(0.06)$ \\
\hline \multirow[t]{2}{*}{ 6-month return } & $-0.285^{* * *}$ & -0.047 \\
\hline & $(0.07)$ & $(0.10)$ \\
\hline \multirow[t]{2}{*}{ 36-month return } & 0.032 & 0.024 \\
\hline & $(0.02)$ & $(0.03)$ \\
\hline \multirow[t]{2}{*}{ Turnover ratio } & -0.054 & 0.02 \\
\hline & $(0.08)$ & $(0.08)$ \\
\hline \multirow[t]{2}{*}{ RE investment growth } & 0.03 & $0.065^{* *}$ \\
\hline & $(0.02)$ & $(0.03)$ \\
\hline \multirow[t]{2}{*}{ ROAE } & 0.025 & 0.001 \\
\hline & $(0.08)$ & $(0.10)$ \\
\hline \multirow[t]{2}{*}{ Federal funds rate $(\%)$} & $-0.161^{* *}$ & -0.010 \\
\hline & $(0.08)$ & $(0.10)$ \\
\hline \multirow[t]{2}{*}{ NBER business cycle indicator } & $-0.848^{* * *}$ & 0.108 \\
\hline & $(0.27)$ & $(0.35)$ \\
\hline \multirow[t]{2}{*}{ L.beta } & $0.077^{* *}$ & 0.003 \\
\hline & $(0.03)$ & $(0.04)$ \\
\hline \multirow[t]{2}{*}{ L.jstat } & $0.590^{* * *}$ & $0.468^{* * *}$ \\
\hline & $(0.02)$ & $(0.02)$ \\
\hline \multirow[t]{2}{*}{ Constant } & 0.197 & -0.177 \\
\hline & $(0.28)$ & $(0.29)$ \\
\hline Observations & 2,441 & 1,387 \\
\hline R-squared & 0.447 & 0.551 \\
\hline Sector effects & Yes & Yes \\
\hline Quarter effects & Yes & Yes \\
\hline
\end{tabular}

Table 12

The table presents the regression results for the firm-quarter observations of the positive and negative Adjusted J statistics, with respect to the S\&P500, estimated separately. The lags of the Adjusted J statistic estimates are included as a control variable. Market leverage is measured as Total Debt divided by the Market Value of Assets (Total Assets minus Book Equity + Market value of Equity). Firm size is the natural logarithm of the Market Capitalisation. Market-to-book ratio is the Market Value of Assets divided by the book value of Total Assets. 6month return is the 6-month cumulative total return. 36-month return is the 36-month cumulative total return. Turnover ratio is quarterly Trading volume divided by Common Shares Outstanding. Real estate investment growth measures the rate of investment. Return on average equity measures profitability. L.Beta is the first lag of the singlefactor beta. All firm-level data and return data on the firms and the S\&P500 is obtained form SNL Financial. Data on the federal funds rate is obtained from the Federal Reserve Bank of St Louis's Economic Database and business cycle indicators are from NBER. Standard errors, shown in parentheses, are robust to the estimated dependent variable bias, using the weighting procedure proposed in Hornstein and Greene (2012). Significance is indicated as follows: *** $\mathrm{p}<0.01,{ }^{* *} \mathrm{p}<0.05, * \mathrm{p}<0.1$. 


\section{Appendices}

\section{A Longer term regressions}

Regression results for six-months and one-year ahead beta and Adjusted J statistic with respect to
S\&P 500 index

\begin{tabular}{|c|c|c|c|c|}
\hline & (1) & $(2)$ & (3) & $(4)$ \\
\hline VARIABLES & 6 months Beta & 6 months J statistic & 1 year Beta & 1 year $J$ statistic \\
\hline \multirow[t]{2}{*}{ Market leverage } & $0.072^{*}$ & $-0.220 * * *$ & 0.062 & $-0.248^{* * *}$ \\
\hline & $(0.04)$ & $(0.08)$ & $(0.04)$ & $(0.09)$ \\
\hline \multirow[t]{2}{*}{ Log of firm size } & $0.053^{* * *}$ & $0.046^{* * *}$ & $0.063^{* * *}$ & $0.066^{* * *}$ \\
\hline & 0.00 & $(0.01)$ & 0.00 & $(0.01)$ \\
\hline \multirow[t]{2}{*}{ Market to book ratio } & $-0.099 * * *$ & $-0.083^{*}$ & $-0.112^{* * *}$ & -0.073 \\
\hline & $(0.02)$ & $(0.05)$ & $(0.02)$ & $(0.05)$ \\
\hline \multirow[t]{2}{*}{ 6-month return } & 0.039 & $-0.348^{* * *}$ & $0.081^{* *}$ & 0.054 \\
\hline & $(0.03)$ & $(0.07)$ & $(0.04)$ & $(0.08)$ \\
\hline \multirow[t]{2}{*}{ 36-month return } & -0.017 & $0.061^{* * *}$ & -0.011 & $0.061^{* *}$ \\
\hline & $(0.01)$ & $(0.02)$ & $(0.01)$ & $(0.02)$ \\
\hline \multirow[t]{2}{*}{ Turnover ratio } & $0.358 * * *$ & 0.032 & $0.248^{* * *}$ & -0.037 \\
\hline & $(0.04)$ & $(0.07)$ & $(0.04)$ & $(0.08)$ \\
\hline \multirow[t]{2}{*}{ RE investment growth } & 0.012 & 0.008 & -0.011 & 0.01 \\
\hline & $(0.01)$ & $(0.02)$ & $(0.01)$ & $(0.03)$ \\
\hline \multirow[t]{2}{*}{ ROAE } & 0.028 & 0.011 & 0.052 & 0.104 \\
\hline & $(0.04)$ & $(0.08)$ & $(0.04)$ & $(0.08)$ \\
\hline \multirow[t]{2}{*}{ Federal funds rate $(\%)$} & -0.017 & $-0.173^{* * *}$ & $-0.061 * * *$ & -0.039 \\
\hline & $(0.02)$ & $(0.03)$ & $(0.02)$ & $(0.04)$ \\
\hline \multirow[t]{2}{*}{ NBER business cycle indicator } & $0.271^{* * *}$ & $0.928^{* * *}$ & $-0.228^{* * *}$ & $0.400^{* *}$ \\
\hline & $(0.08)$ & $(0.16)$ & $(0.08)$ & $(0.17)$ \\
\hline \multirow[t]{2}{*}{ L.beta } & $0.317 * * *$ & -0.02 & $0.301^{* * *}$ & 0.016 \\
\hline & $(0.02)$ & $(0.03)$ & $(0.02)$ & $(0.04)$ \\
\hline \multirow[t]{2}{*}{ L.jstat } & $\mathrm{n} / \mathrm{a}$ & $0.385^{* * *}$ & $\mathrm{n} / \mathrm{a}$ & 0.02 \\
\hline & $\mathrm{n} / \mathrm{a}$ & $(0.02)$ & $\mathrm{n} / \mathrm{a}$ & $(0.02)$ \\
\hline \multirow[t]{2}{*}{ Constant } & $-0.318^{* * *}$ & -0.109 & $-0.252^{* *}$ & $-0.940 * * *$ \\
\hline & $(0.10)$ & $(0.21)$ & $(0.11)$ & $(0.23)$ \\
\hline Observations & 3,735 & 3,723 & 3,529 & 3,520 \\
\hline R-squared & 0.704 & 0.419 & 0.711 & 0.327 \\
\hline Sector effects & Yes & Yes & Yes & Yes \\
\hline Quarter effects & Yes & Yes & Yes & Yes \\
\hline
\end{tabular}

Table A.1

The table presents the regression results for the firm-quarter observations of the 6-months and one-year ahead single-factor beta with respect to the S\&P500 (Column (1)) and the Adjusted J statistic (Column (2)). Variables are defined as in the main analysis. Significance is indicated as follows: $* * * \mathrm{p}<0.01, * * \mathrm{p}<0.05, * \mathrm{p}<0.1$. 